\title{
変動くり返し荷重によるアーチの崩壊 \\ FAILURE OF ARCHES UNDER VARIABLE REPEATED LOADING
}

\section{1. 緒言}

通常の桁構造や単層骨組構造のように, 主として曲げ 部材により構成されている構造物を塑性解析するときに は，断面に生ずる全塑性曲げモーメントの軸方向力によ る低減を無視することができる。このような構造物の塑 性変形により生ずる崩壊メカニズムから求めた崩壊荷重 (以下単に崩壊荷重と呼ぶ), 変動くり返し荷重により構 造物が Shake-down するときの変形硬化荷重に関して は, すでに数多くの研究成果が発表され, 両荷重の開き はさほど大きくはなく, 両荷重の比はほぼ 85\% 以内に あることが明らかにされている。

軸方向力の全塑性曲げモーメントに与える影響が無視 できないようなアーチ構造の塑性解析に関する研究は, 1950 年頃から始められ，なかでも軸方向力と曲げモー メントを含んだ断面の降伏条件式を導き, 上界定理およ び下界定理を用いての Onat and Prager ${ }^{1)}$ の研究は注 目に值するものである。また, 横尾・山肩 ${ }^{2)}$ はアーチの せり高の変化にともなう崩壊時の挙動について興味ある 研究を発表している。模型を用いてのアーチの崩壊に関 する実験的研究をもあわせて, 極限強度に関する研究は すでに数多くあげることができる。

しかしながら, 弾性限を越える荷重がアーチにくり返 し作用した場合, 変動くり返し荷重がアーチ上を移動す るときの構造物の残留変形に関連してくる変形硬化荷重 (Shake-down Load) に対する研究は，あまり例をみる ことができない。Franciosi, V., Augusti, G., and Saracio, R. ${ }^{3)}$ は鉄筋コンクリートアーチ橋を対照に, 等分布死荷重, 等分布活荷重および温度変化を考慮して 崩壊荷重と変形硬化荷重の両者を求めた。解析は上界定 理を用い，図解法をも併用して近似解を求めたものであ る。一数値計算結果によれば, 変形硬化荷重が崩壊荷重 のほぼ 38\% まで低下するような結果を示しており，通 常の曲げのみを考虑した構造物に対する両荷重の比とは 大幅に異なった值を与えており，アーチの塑性解析にお いて, 変形硬化荷重に対する検討が無視できないとして いる。

本研究では, I 形, 箱形または矩形断面をもつ 2 ヒン

* 正会員 Ph.D. 名古屋大学助教授 工学部土木工学科

** 正会賈金沢大学講師 工学部土木工学科
福 本 唀 士*.吉 田 博** By Yuhshi Fukumoto and Hiroshi Yoshida

ジ鋼円弧アーチに等分布死荷重と単一集中荷重が作用し たときのアーチの最小崩壊荷重, また, 集中荷重のくり 返し移動通過によるアーチの変形硬化強度, および断面 に発生する交番塑性応力による断面の破断を定義する交 番塑性荷重を求め, アーチの中心角, アーチ リブの断 面形状, 断面高さをパラメーターとして, これらの荷重 の比較検討を行ない，曲げモーメントと軸方向力が同時 に作用するような構造物の変形硬化荷重に対する理論解 析ならびに, 崩壊荷重との量的比較を明らかにしたもの である。

\section{2. 用いた仮定および降伏条件式}

解析に用いた仮定はつぎのようである。

1）使用材料は完全弾塑性体である。

2) 断面の降伏条件式には曲げモーメントおよび軸方 向力のみを考慮し, せん断力の影響は無視する。

3）アーチの座屈および不安定現象による崩壊は考え ない。

Fig. 1

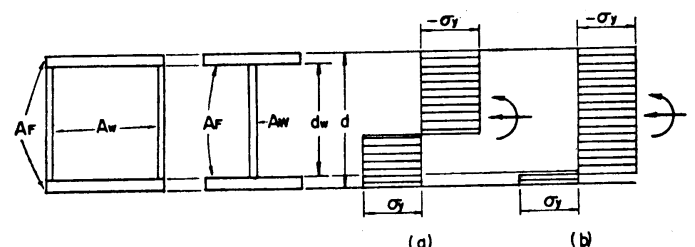

(a)

以上の仮定により，図一1 に示すような I 形または箱 形断面の部材が曲げモーメントと軸方向を受ける場合の 降伏条件式は, 両フランジ断面積 $A_{F}$ とウェブ断面積 $A_{W}$ の比 $A_{F} / A_{W}$ とアーチリブ断面の高さ $d$ とウェブ 高 $d_{w}$ の比 $d / d_{w}$ をパラメーターとして次式で表わさ れる4。

$$
\left.\begin{array}{c}
\left|\frac{M}{M_{p}}\right|=1.00-k\left(\frac{N}{N_{y}}\right)^{2} \\
0 \leqq \frac{N}{N y} \leqq \frac{1}{1+\left(A_{F} / A_{w}\right)}
\end{array}\right\}
$$$$
\text { ここに, }
$$ 
Fig. 2 Interaction curves between Axial Thrust and Bending Moment.

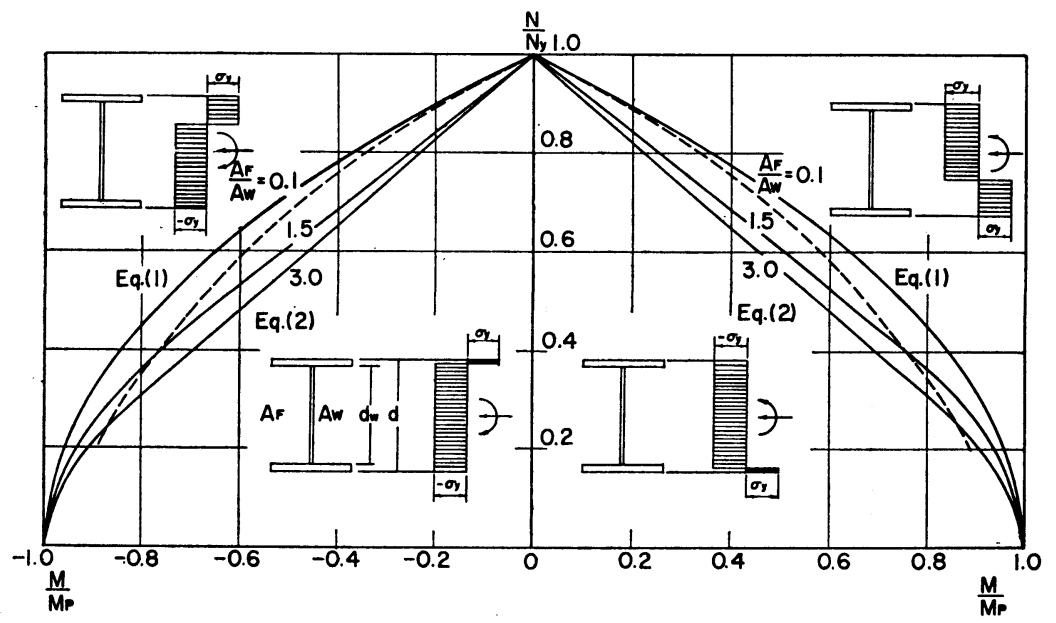

ことができる。

左右非対称荷重を受ける 2 ヒンジアーチは 2 個の塑性 ヒンジ形成により崩壊にいた る。いま，任意の 2 点に塑性 ヒンジができたとすると, そ れらの 2 断面での曲げモーメ ントおよび軸方向力は降伏条 件式（1）または（2）を満足 しなければならない。しかし ながら, 塑性ヒンジの位置を 任意に仮定しているため必ず しもアーチ全断面で塑性モー メント条件を満足していると は限らない。したがって, 改

$$
\begin{aligned}
& k=\frac{\left\{\left(A_{F} / A_{W}\right)+1\right\}^{2}}{\left\{\left(d / d_{w}\right)+1\right\}\left(A_{F} / A_{w}\right)+1} \\
& \left.k^{\prime}=\frac{\left\{\left(d / d_{w}\right)+1\right\}}{\left\{\left(d / d_{w}\right)+1\right\}\left(A_{F} / A_{w}\right)+1}\right\}
\end{aligned}
$$

$M_{p}=$ 全塑性モーメント, $N_{y}=A \sigma_{y}$ 二軸方向力のみによ る全断面降伏力, $A=A_{F}+A_{W}=$ 全断面積, $M=$ 作用曲 げモーメント, $N=$ 作用軸方向力, $\sigma_{y}=$ 降伏点応力 である。

式 (1) は塑性ヒンジ形成時の断面の中立軸がウェブ内 にあるときの（図一1(a)）曲げモーメントと軸方向力の 降伏条件式を示したものであり, 式 (2) は中立軸がフラ ンジ内にあるときの（図一1(b)）降伏条件式を直線式で 近似したものである。すなわち, 式 (2) は $N / N_{y}=1 / 1+$ $\left(A_{F} / A_{W}\right)$ で式 (1) に交わり, $M / M_{p}=0$ で $N / N_{y}=1$ を通る直線式とおいた近似式であり,この範囲では厳密 式もほとんど直線式と一致している。

図一2 は $d / d_{w}=1.1$ とし, $A_{F} / A_{W}=0.1$ すなわち, 矩形断面の降伏条件式 $\left|M / M_{p}\right|=1.00-\left(N / N_{y}\right)^{2}$ と $A_{F} / A_{W}=1.5,3.0$ のときの塑性ヒンジ形成に対する曲 げモーメントと軸方向力の組み合わせのときの降伏条件 式 (1),(2)を示したものである。同図には式 (1) および 式 (2) の適用範囲が破線にて示されている。

以下の計算に当っては, 降伏条件式として式 (1) と式 （2）を用い, 通常のアーチの充腹 I 形断面リブではほぼ $d / d_{w}=1.1$ であるので, 断面のパラメーターとして, $A_{F} / A_{W}$ のみを用いる。

\section{3. 崩壞荷重}

図一3 に示すよ5に中心角 $2 \phi$ を有する 2 ヒンジ円弧 アーチにスパン $2 L_{0}$ にわたり, 単位長さ当り $\alpha \cdot N_{y} / L_{0}$ の等分布死荷重, およびスパン中央点 $C$ より $\theta$ をなす 位置 $d_{0}$ に単一集中荷重 $P$ が作用した場合のアーチの 崩壊荷重は，下界定理を用いてつぎのようにして求める
めて塑性ヒンジの位置を仮定して崩壊荷重を求め, それ らの荷重のうち最も小さいものが真の崩壊荷重を与え る。以下に図一3に示す荷重状態の崩壊荷重を求める解 析順序を示す。

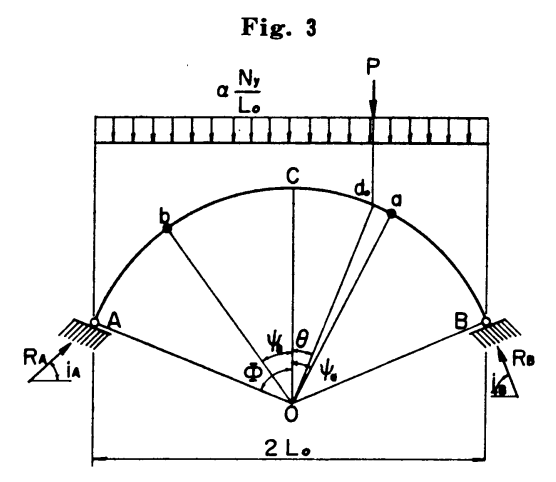

（1）支点 $A$ の反力 $R_{A}$ が水平となす角を $i_{A}$ とし $i_{A}$ を末知量とする。支点 $B$ に関するつりあい条件より 集中荷重 $P$ は次式のように表わされる。

$$
P=\frac{2 \sin i_{A} \cdot \sin \phi}{\sin \phi-\sin \theta} R_{A}-\frac{2 \alpha \sin \phi}{\sin \phi-\sin \theta} N_{y} \cdots
$$

（2） スパン中央 $C$ より支点 $B$ 側に角 $\psi_{a}$ 傾いた 点 $a$, および $C$ より支点 $A$ 側に角 $\psi_{b}$ 傾いた点 $b$ に 塑性ヒンジが生じたと仮定する。 $a, b$ 点での曲げモーメ ントおよび軸方向力をそれぞれ $M_{a}, M_{b}$ および $N_{a}, N_{b}$ とすると,

$$
\left.\begin{array}{rl}
M_{a} & =\left(A_{a} R_{A}+B_{a} N_{y}\right) L_{0} \\
N_{a} & =C_{a} R_{A}+D_{a} N_{y} \\
M_{b} & =\left(A_{b} R_{A}+B_{b} N_{y}\right) L_{0} \\
N_{b} & =C_{b} R_{A}+D_{b} N_{y}
\end{array}\right\}
$$

で示される。ただし, 軸方向力は圧縮力を正, 曲げモー メントは断面の上縁が圧縮側になる方向を正とする。 ここに, 


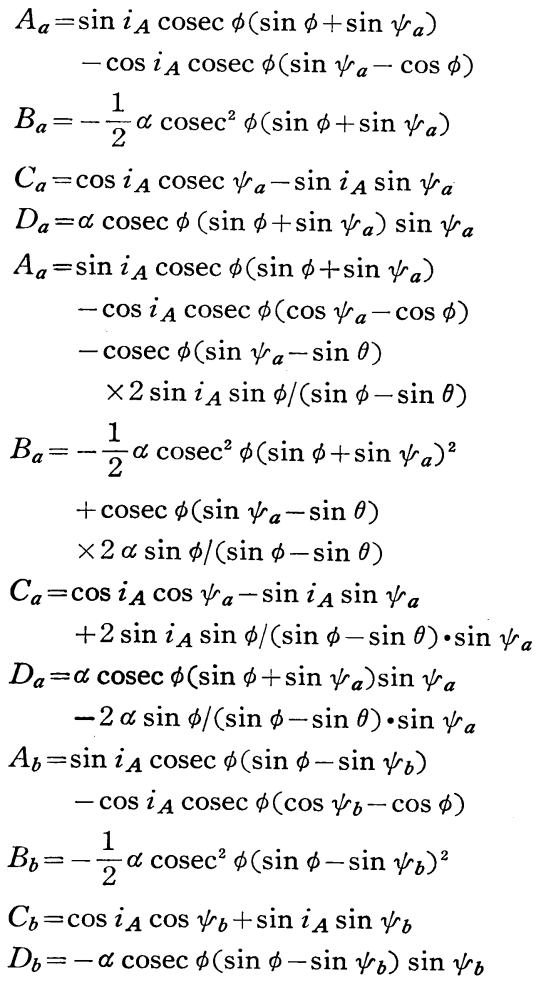

（3） $a, b$ 点では軸方向力の大小により降伏条件式 （1）または（2）を満足しなければならない。一方，この 軸方向力の大小は集中荷重 $P$ の位置により決められる。 図一3 に示すように， $P$ の位置がスパン中央より $B$ 支 点側にあるときは $a$ 点より $b$ 点での軸方向力が常に大 きく, 全断面降伏時の中立軸の位置はつぎの 3 つの場合 が考えられる。

a) $a, b$ 点とも中立軸がウェブ内にある場合 $a, b$ 点とも降伏条件式 (1) を満足する。したがって, 式 (5) および式 (6) を式 (1) に代入すると，

$$
\begin{aligned}
& \left.\left|\frac{\left(A_{a} R_{A}+B_{a} N_{y}\right) L_{0}}{M_{p}}\right|=1.00-k\left(\frac{C_{a} R_{A}+D_{a} N_{y}}{N_{y}}\right)^{2}\right) \\
& \left.\left|\frac{\left(A_{b} R_{A}+B_{b} N_{y}\right) L_{0}}{M_{p}}\right|=1.00-k\left(\frac{C_{b} R_{A}+D_{b} N_{y}}{N_{y}}\right)^{2}\right\}
\end{aligned}
$$

となる。一方, 全塑性モーメント $M_{p}$ と軸方向力のみ による全断面降伏力 $N_{y}$ の比はつぎの関係がある。

$$
\frac{M_{p}}{N_{y}}=\frac{Z}{A}=\lambda d, \quad \lambda=\frac{\left(A_{F} / A_{w}\right)+1}{4 k\left(d / d_{w}\right)}
$$

ここに, $Z$ は塑性断面係数である。また，

$$
R_{A} / N_{y}=Q
$$

とおけば式 (9) を用いて, 式 (7) を書きかえると,

$$
\left.\begin{array}{l}
A_{1} Q+B_{1}=1.00-k\left(C_{a} Q+D_{a}\right)^{2} \\
A_{2} Q+B_{2}=1.0 C-k\left(C_{b} Q+D_{b}\right)^{2}
\end{array}\right\}
$$

となる。ここに，

$$
\left.\begin{array}{rl}
\delta & =d / L_{0} \\
A_{1} & \left.=A_{b} / \lambda \delta, B_{1}=B_{a} / \lambda \delta, A_{2}=A_{b} / \lambda \delta, B_{2}=B_{b} / \lambda \delta\right\}
\end{array}\right\}
$$

式 (10) の連立方程式を解き， $Q$ および $i_{A}$ を求める ことができる。

b） $a$ 断面の中立軸がウェブ内にあり， $b$ 断面の中立 軸がフランジ内にある場合 $\quad a$ 点においては式 (1)の 降伏条件式を, $b$ 点においては式 (2) の降伏条件式を満 足しなければならない。式 (5) を式 (1) に, 式 (6)を 式（2）に代入し，式（9）および式（11）を用いること により,

$$
\left.\begin{array}{l}
A_{1} Q+B_{1}=1.00-k\left(C_{a} Q+D_{a}\right)^{2} \\
A_{2} Q+B_{2}=k^{\prime}\left\{1.00-\left(C_{b} Q+D_{b}\right)\right\}
\end{array}\right\}
$$

となる。この連立方程式を解くことにより $Q$ および $i_{A}$ が求められる。

\section{c) $a, b$ 断面とも中立軸がフランジ内にある場合} $a, b$ 点とも式 (2) の降伏条件式を満足しなければならな い。式 (5) および式 (6) を式 (2) に代入し, 式 (9) および式 (11) を用いることにより，

$$
\left.\begin{array}{l}
A_{1} Q+B_{1}=k^{\prime}\left\{1.00-\left(C_{a} Q+D_{a}\right)\right\} \\
A_{2} Q+B_{2}=k^{\prime}\left\{1.00-\left(C_{b} Q+D_{b}\right)\right\}
\end{array}\right\}
$$

となり，この連立方程式を解いて $Q$ および $i_{A}$ を求め ることができる。

(4) $a, b$ 断面で全断面降伏時において仮定した中立 軸の位置が, 真の值かどうかは a), b) および $\mathbf{c}$ ) で求 めた $Q$ および $i_{A}$ から計算した $a, b$ 断面での 軸方向 力を $N$ とすると, $N / N_{y} \gtrless 1 / 1+\left(A_{F} / A_{W}\right)$ の条件から 中立軸が仮定したものと一致するかどらかにより求める ことができる。

（5）以上で求まった真の $Q$ および $i_{A}$ を式 (4) に 代入して $P$ を求めることができる。

（6）（5）で求まった崩壊荷重 $P$ は，任意に仮定し た $a, b$ 断面にて塑性ヒンジが形成すると考えたが, こ の場合，必ずしも塑性モーメント条件を満足していな い。塑性モーメント条件を満足するためには $\psi_{a}, \psi_{b}$ $\left(0<\psi_{a}, \psi_{b}<\phi\right)$ のあらゆる組み合わせに対して $P$ の 最小值を求めねばならない。すなわち, この $P$ の最小 值が与えられた荷重位置での真の崩壊荷重である。

（7）アーチの真の崩壊荷重は $P$ の載荷位置 $\theta$ を $0 \sim \phi$ まで変化させて上記 (1) （6）の解析順序をくり返 した場合の $P$ の最小值として与えられる。

単一集中荷重のみによる崩壊荷重はつぎのようにして 求めることができる。図一4のように, 支点 $A$ の反力 Fig. 4

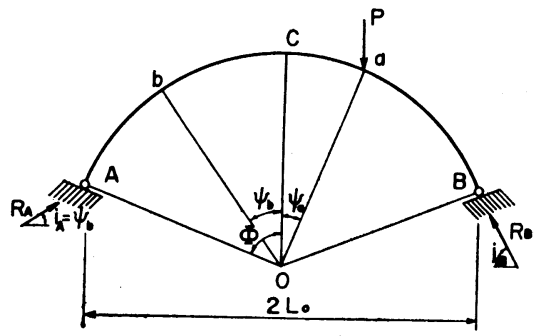


$R_{A}$ の水平となす角を $i_{A}$ とすると塑性ヒンジ形成の位 置は最大曲げモーメントの位置の荷重点 $a$ と負の最大曲 げモーメントおよび最大軸方向力が同時に生ずる位置, すなわち，スパン中央より支点 $A$ 側に $i_{A}$ だけ傾いた 点 $b$ に生ずる。したがって，それらの点における曲げ モーメント, 軸方向力を降伏条件式（1）または（2）に 代入することにより崩壊荷重を求めることができる。

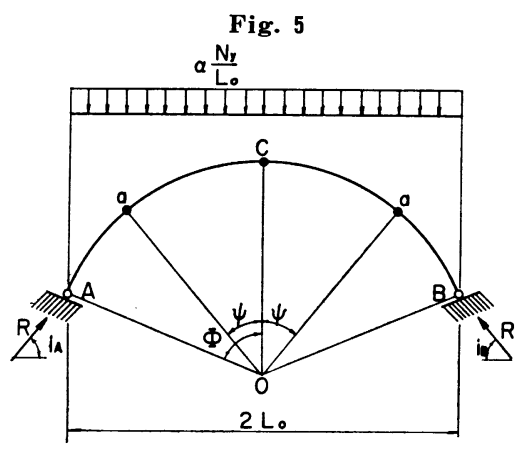

等分布荷重のみが載荷される場合のアーチの崩壊は図 -5 のごとくスパン中央点 $C$ および左右対称の位置 $a$, $a^{\prime}$ にて 3 つの塑性ヒンジを生じて崩壊する。したがって この場合の崩壊荷重はスパン中央点 $C$ より $A$ 支点側 および $B$ 支点側に $\psi$ 傾いた点 $a, a^{\prime}$ にて塑性ヒンジ

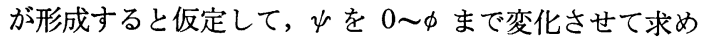
た崩壊荷重の最小值が等分布荷による真の崩重壊荷重で ある。なお，崩壊荷重の計算結果は 6.にまとめてある。

\section{4. 变形硬化荷重}

くり返し移動荷重によるアーチの変形硬化現象を例に よって説明する。いま, 図一6(a) のように中心角 $2 \phi=$ $120^{\circ}$, アーチ リブ断面が $d / d_{w}=1.1, A_{F} / A_{W}=1.5$ の アーチ上を $P=0.1442 N_{y}$ なる単一集中荷重が支点 $B$ より支点 $A$ 方向に転動する場合, $a$ 点 $\left(\psi_{a}=31.64^{\circ}\right)$ および $b$ 点 $\left(\psi_{b}=26.82^{\circ}\right)$ における曲げモーメントを $M_{a x}, M_{b x}$, 軸方向力を $N_{a x}, N_{b x}$ とすると，それらの $P=0.1442 N_{y}$ による影響線は図一6(b), (c) の曲線 (1), (3)のようになる。ここに, 綐軸は $M_{p}$ および $N_{y}$ で無 次元化してある。また, 降伏条件式の左辺 $\left|M_{a x} / M_{p}\right|+$ $k\left(N_{a x} / N_{y}\right)^{2},\left|M_{b x} / M_{p}\right|+k\left(N_{b x} / N_{y}\right)^{2}$ の值は 図一6(d) の曲線 (1),(3) の上うになる。まず, 荷重が支点 $B$ 上に あるとき， $M_{a x}=0, N_{a x}=0$ であるが，支点 $A$ 方向に 荷重が進むとともに $M_{a x}, N_{a x}$ の值は増加し， $x_{1}$ の 点に荷重が到達したとき, $\left|M_{a x} / M_{p}\right|+k\left(N_{a x} / N_{y}\right)^{2}=1$ となる。すなわち $x_{1}$ 点まで荷重が進んだとき $a$ 点では 塑性ヒンジの回転が始まる。さらに荷重が $a$ 点に達して 塑性ヒンジの回転角は最大となる。 $a$ 点に荷重が達した とき，もし荷重を除去しても塑性変形の結果による曲げ モーメントおよび軸方向力が残留する。したがって，荷 重が $a$ 点を通過すると $a$ 点には弾性曲げモーメント
Fig. 6 Shake-Down Loading.

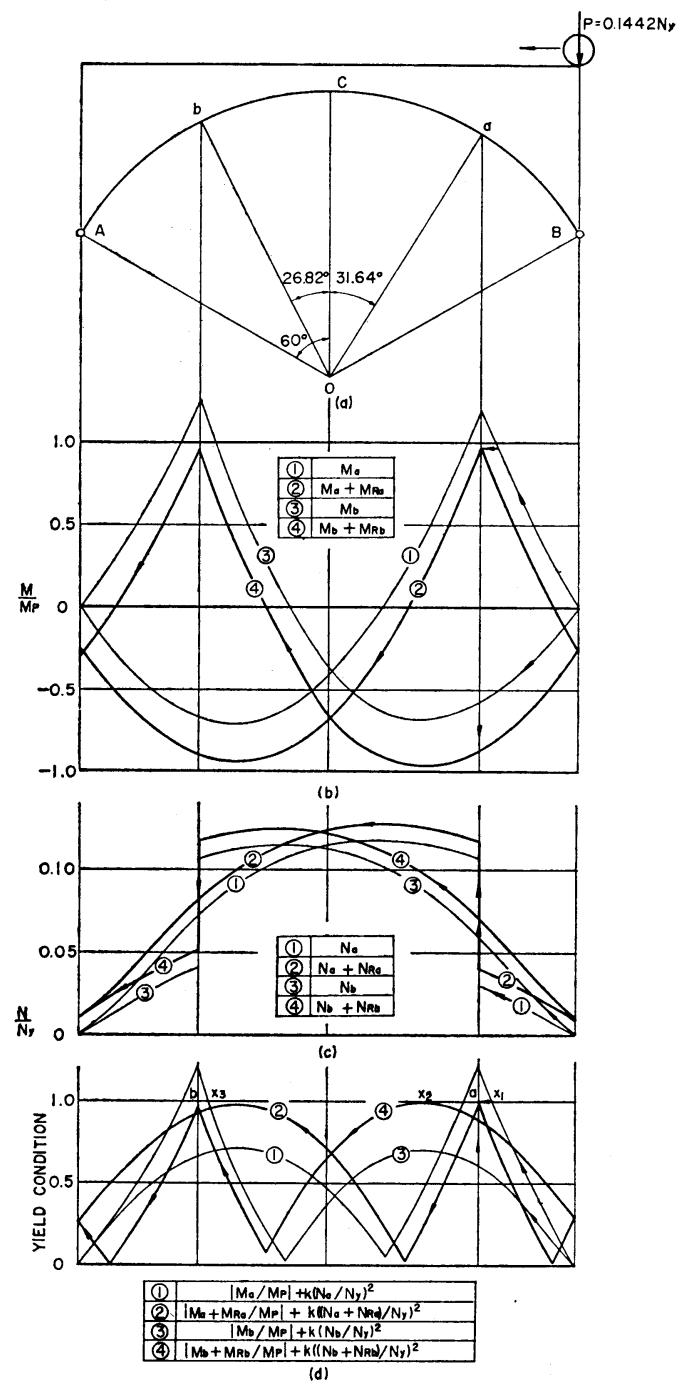

$M_{a x}$, 弾性軸方向力 $N_{a x}$ のほかに残留曲げ モーメント $M_{R a}$, 残留軸方向力 $N_{R a}$ が作用することになる。 $a, b$ 点における残留曲げモーメントおよび残留軸方向力を, $a, b$ 点における曲げモーメント影響線 (図一6(b) (1),(3) および軸方向力影響線（図一6 (c) (1), (3)）にそれぞれ加 えたものを図一6 (b), (c) の曲線 (2), (4) で示してある。 そして, それらの組み合わせ $\left|\left(M_{a x}+M_{R a}\right) / M_{p}\right|+$ $k\left(\left(N_{a x}+N_{R a}\right) / N_{y}\right)^{2}$ は 図一6(d) の曲線(2)のようにな り, 以後荷重の進行とともにその值は 1 を越えることは ない。一方, $b$ 点の曲げモーメントおよび軸方向力は荷 重が支点 $B$ 上では $M_{b x}=0, N_{b x}=0$ であるが, 荷重が 支点 $A$ 方向に進むとともに, $M_{b x}$ の絶対值および $N_{b x}$ は増加する。そして, それらの組み合わせ $\left|M_{b x} / M_{p}\right|+$ $k\left(N_{b x} / N_{y}\right)^{2}$ の值も増加する。荷重が $a$ 点に達すると $b$ 点には弾性曲げモーメント $M_{b x}$ および弾性軸方向力 $N_{b x}$ のほかに $a$ 点の塑性変形による残留曲げモーメン 
ト $M_{R b}$ および残留軸方向力 $N_{R b}$ が作用し, 荷重が $a$ 点 を通過するとそれらの組み合わせは $\left|\left(M_{b x}+M_{R b}\right) / M_{p}\right|$ $+k\left(\left(N_{b x} / N_{y}\right)^{2}\right.$ となり荷重が $x_{2}$ に到達してその值は 1 となり， $b$ 点に塑性ヒンジが形成される。しかし， $x_{2}$ の点を荷重が通過するとただちにその值は減少し, $b$ 点 に塑性変形を残さない。もし, 荷重が与えられた $P=$ $0.1442 N_{y}$ より少しでも大きいと $b$ 点に塑性変形を生ず ることになる。荷重の移動とともに $\left|M_{b x}+M_{R b} / M_{p}\right|+$ $\left.k\left(N_{b x}+N_{R b}\right) / N_{y}\right)^{2}$ の值はいったん減少する。曲線 (3) に沿っていくと荷重が $x_{3}$ の点に到達して $\left|\left(M_{b x} / M_{p}\right)\right|+$ $k\left(\left(N_{b x} / N_{y}\right)^{2}=1\right.$ となり, $b$ 点上ではその值は 1 を越す ことになる。しかし， $a$ 点の残留変形を考慮すると（曲 線 (4)) 曲げモーメントと軸方向力の組み合わせは, $\left|\left(M_{b x}+M_{R b}\right) / M_{p}\right|+k\left(\left(N_{b x}+N_{R b}\right) / N_{y}\right)^{2}<1$ となり, $b$ 点では塑性ヒンジは形成されない。したがって荷重の 最初の 1 回の通過では $a$ 点および $b$ 点の曲げモーメン 卜, 軸方向力およびそれらの組み合わせの変化は 図一6 (b), (c), (d) の矢印で示したように変化する。第 2 回以 後の荷重の通過では, $a$ 点の塑性変形の影響により図一6 (b), (c), (d) の太線（曲線 (2), (4)) の上うにそれぞれ変 化し, $a$ 点および $b$ 点では塑性ヒンジは 1 時的に形成す るが塑性変形は増大しない。すなわち, 第 2 回目以後の この荷重の通過によりアーチは完全に弾性的挙動を示す ことになる。このような現象をアーチが変形硬化すると 呼び, この荷重が変形硬化荷重である。以下にこの変形 硬化荷重を下界定理を用いて求める方法について述べ る。

Fig. 7

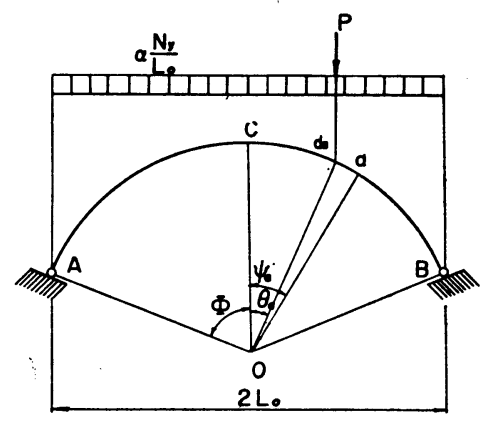

図一7 のように等分布荷重と単一集中荷重が作用する 場合の $a$ 点での弾性曲げモーメントおよび弾性軸方向力 を $M_{a}, N_{a}$ とすると，

$$
\left.\begin{array}{l}
M_{a}=\left(A_{M a} P+B_{M a} N_{y}\right) L_{0} \\
N_{a}=A_{N a} P+B_{N a} N_{y}
\end{array}\right\}
$$

となる。また, 図一8 のような載荷状態での $b$ 点の弾性 曲げモーメントおよび弾性軸方向力を $M_{b}, N_{b}$ とする と,

$$
\left.\begin{array}{rl}
M_{b} & =\left(A_{M b} P+B_{M b} N_{y}\right) L_{0} \\
N_{b} & =A_{N b} P+B_{N b} N_{y}
\end{array}\right\}
$$

で与えられる。ただし，
Fig. 8

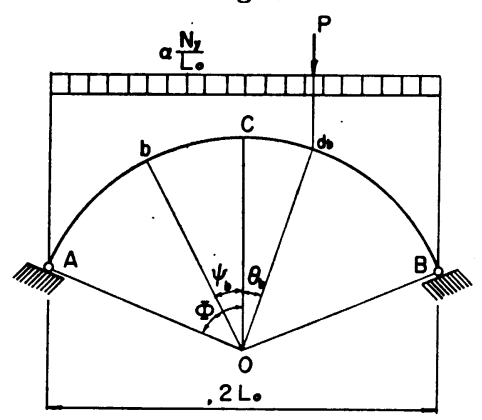

$$
\left.\begin{array}{rl}
A_{M a}= & \left(\sin \phi-\sin \theta_{a}\right) / 2 \sin \phi \cdot \operatorname{cosec} \phi\left(\sin \phi+\sin \psi_{a}\right) \\
& -A_{a} \operatorname{cosec} \phi\left(\cos \psi_{a}-\cos \phi\right) \\
B_{M a}= & \alpha \operatorname{cosec} \phi\left(\sin \phi+\sin \psi_{a}\right) \\
& -B_{a} \operatorname{cosec} \phi\left(\cos \psi_{a}-\cos \phi\right) \\
& -\frac{1}{2} \alpha \operatorname{cosec}^{2} \phi\left(\sin \phi+\sin \psi_{a}\right)^{2} \\
A_{N a}= & A_{a} \cos \psi_{a}-\left(\sin \phi-\sin \theta_{a}\right) / 2 \sin \phi_{a} \cdot \sin \psi_{a} \\
B_{N a}= & B_{a} \cos \psi_{a}-\left(\sin \phi+\sin \theta_{a}\right) / 2 \sin \phi \cdot \psi_{a} \\
& +\alpha \operatorname{cosec} \phi\left(\sin \phi+\sin \psi_{a}\right) \sin \psi_{a}
\end{array}\right\}
$$

$\psi_{a} \leqq \theta_{a}$

$A_{M a}=\left(\sin \phi+\sin \theta_{a}\right) / 2 \sin \phi \cdot \operatorname{cosec} \phi\left(\sin \phi-\sin \psi_{a}\right)$

$-A_{a} \operatorname{cosec} \phi\left(\cos \psi_{a}-\cos \phi\right)$

$B_{M a}=\alpha \operatorname{cosec} \phi\left(\sin \phi-\sin \psi_{a}\right)$

$-B_{a} \operatorname{cosec} \phi\left(\cos \psi_{a}-\cos \phi\right)$

$-\frac{1}{2} \alpha \operatorname{cosec}^{2} \phi\left(\sin \phi-\sin \psi_{a}\right)^{2}$

$A_{N a}=A_{a} \cos \psi_{a}+\left(\sin \phi+\sin \theta_{a}\right) / 2 \sin \phi \cdot \sin \psi_{a}$

$B_{N a}=B_{a} \cos \psi_{a}+\alpha \sin \psi_{a}$

$-\alpha \operatorname{cosec} \phi \sin \psi_{a}\left(\sin \phi-\sin \psi_{a}\right)$

$\psi_{a} \geqq \theta_{a}$

$A_{M b}=\left(\sin \phi-\sin \theta_{b}\right) / 2 \sin \phi \cdot \operatorname{cosec} \phi\left(\sin \phi-\sin \psi_{b}\right)$

$-A_{b} \operatorname{cosec} \phi\left(\cos \psi_{b}-\cos \phi\right)$

$B_{M b}=\alpha \operatorname{cosec} \phi\left(\sin \phi-\sin \psi_{b}\right)$

$-B_{a} \operatorname{cosec} \phi\left(\cos \psi_{b}-\cos \phi\right)$

$-\frac{1}{2} \alpha \operatorname{cosec}^{2} \phi\left(\sin \phi-\sin \psi_{b}\right)^{2}$

$A_{N b}=A_{b} \cos \psi_{b}+\left(\sin \phi-\sin \theta_{b}\right) / 2 \sin \phi \cdot \sin \psi_{b}$

$B_{N b}=B_{a} \cos \psi_{b}$

$+\alpha \sin \psi_{b}-\alpha \operatorname{cosec} \phi \sin \psi_{b}\left(\sin \phi-\sin \psi_{b}\right)$

Fig. 9

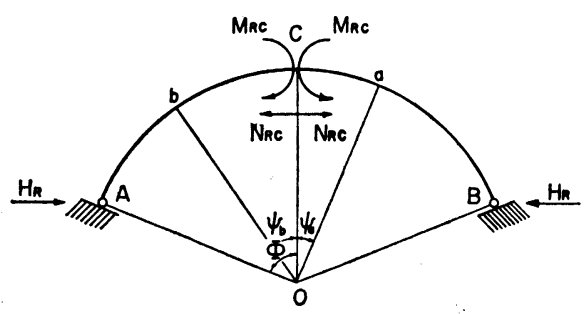




$$
\begin{aligned}
A_{a} & =\frac{1}{2} \frac{\sin ^{2} \phi-\sin ^{2} \theta_{a}-2 \cos \phi\left(\phi \sin \phi-\theta_{a} \sin \theta_{a}+\cos \phi-\cos \theta_{a}\right)-r\left(\sin ^{2} \phi-\sin ^{2} \theta_{a}\right)}{\phi-3 \sin \phi \cos \phi+2 \phi \cos ^{2} \phi+r(\phi+\sin \phi \cos \phi)} \\
B_{a} & =\frac{\alpha}{2} \frac{4 / 3 \cdot \sin ^{3} \phi+\phi \cos \phi-2 \phi \sin ^{2} \phi \cos \phi-\sin \phi \cos ^{2} \phi+2 r\left(\phi \cos ^{2} \phi-\frac{1}{2} \phi-\frac{1}{2} \sin \phi \cos \phi\right)}{\phi-3 \sin \phi \cos \phi+2 \phi \cos ^{2} \phi+r(\phi+\sin \phi \cos \phi)} \\
A_{b} & =\frac{1}{2} \frac{\sin ^{2} \phi-\sin ^{2} \theta_{b}-2 \cos \phi\left(\phi \sin \phi-\theta_{b} \sin \theta_{b}+\cos \phi-\cos \theta_{b}\right)-r\left(\sin ^{2} \phi-\sin ^{2} \theta_{b}\right)}{\phi-3 \sin \phi \cos \phi+2 \phi \cos ^{2} \phi+r(\phi+\sin \phi \cos \phi)} \\
r & =\frac{12\left\{1+\left(A_{F} / A_{W}\right)\right\}}{3\left[1+\frac{1}{2}\left\{\left(d / d_{w}\right)-1\right\}\right]^{2}\left(A_{F} / A_{W}\right)+1} \quad \text { 式 (21) の連立方程式を解いて } Q, R \text { を求みることがで }
\end{aligned}
$$$$
\times \frac{1}{\delta\left(d / d_{w}\right)^{2}}
$$

一方, 残留変形による残留反力は 図一9 のように水平 反力のみであり，それを $H_{R}$ とすると $a, b$ 点における 残留曲げモーメント $M_{R a}, M_{R b}$ および残留軸方向力 $N_{R a}, N_{R b}$ は,

$$
\left.\begin{array}{rl}
M_{R a} & =-\operatorname{cosec} \phi\left(\cos \psi_{a}-\cos \phi\right) H_{R} L_{0} \\
N_{R a} & =\cos \psi_{a} H_{R} \\
M_{R b} & =-\operatorname{cosec} \phi\left(\cos \psi_{b}-\cos \phi\right) H_{R} L_{0} \\
N_{R b} & =\cos \psi_{b} H_{R}
\end{array}\right\} \cdots
$$

で与えられる。

いま, $a, b$ 点にて塑性ヒンジが形成されるものとする と, $a, b$ 点における弾性曲げモーメントと残留曲げモー メントの和および弾性軸方向力と残留軸方向力の和は降 伏条件式 (1) または式 (2) を満足しなければならない。 いま，考えているアーチにおいて，Pの位置がスパン中 央より $B$ 支点側にあるとき, 軸方向力は常に $a$ 点より も $b$ 点で大であるので, 軸方向力の大小により全断面降 伏時の断面の中立軸の位置はつぎの 3 つの場合が考えら れる。

a) $a, b$ 点とも中立軸がウェブ内にある場合 $\quad a, b$ 点とも降伏条件式 (1) を満足する。したがって式 (14), (17) および式 (15)，(18）を式 (1) に代入すると,

$$
\left.\begin{array}{c}
\frac{\left(A_{M a} P+B_{M a} N_{y}\right) L_{0}+M_{R a}}{M_{p}}=1.00 \\
-k\left(\frac{A_{N a} P+B_{N a} N_{y}+N_{R a}}{N_{y}}\right)^{2} \\
\frac{\left(A_{M b} P+B_{M b} N_{y}\right) L_{0}+M_{R b}}{M_{p}}=1.00 \\
-k\left(\frac{A_{N b} P+B_{N b} N_{y}+N_{R b}}{N_{y}}\right)^{2}
\end{array}\right\}
$$

となる。式 (8) および $P / N_{y}=Q, H_{R} / N_{y}=R \cdots(20)$ を用いると，

$$
\left.\begin{array}{l}
a_{1} Q+b_{1} R+c_{1}=1.00-k\left(A_{N a} Q+\cos \psi_{a} R+B_{N a}\right)^{2} \\
a_{2} Q+b_{2} R+c_{2}=1.00-k\left(A_{N b} Q+\cos \psi_{b} R+B_{N b}\right)^{2}
\end{array}\right\}
$$

となる。ただし，

$$
\left.\begin{array}{ll}
a_{1}=A_{M a} / \lambda \delta, & b_{1}=\operatorname{cosec} \phi\left(\cos \psi_{a}-\cos \phi\right) / \lambda \delta \\
a_{2}=-A_{M b} / \lambda \delta, & b_{2}=\operatorname{cosec} \phi\left(\cos \psi_{b}-\cos \phi\right) / \lambda \delta \\
c_{1}=B_{M a} / \lambda \delta, & c_{2}=-B_{M b} / \lambda \delta
\end{array}\right\}
$$

b） $a$ 点における中立軸がウェブ内にあり， $b$ 点にお ける中立軸がフランジ内にある場合 $\quad a$ 点においては 式（1）の降伏条件式を， $b$ 点においては式 (2) の降伏 条件式を満足しなければならない。したがって式 (14), （17）を式（1）に，また，式 (15),(18) を式 (2) に代 入し，式 (8)，(20) および (22) を用いると,

$$
\left.\begin{array}{l}
a_{1} Q+b_{1} R+c_{1}=1.00-k\left(A_{N a} Q+\cos \psi_{a} R+B_{N a}\right)^{2} \\
a_{2} Q+b_{2} R+c_{2}=k^{\prime}\left\{1.00-\left(A_{N b} Q+\cos \psi_{a} R+B_{N b}\right)\right\}
\end{array}\right\}
$$

となり，この連立方程式を解いて $Q, R$ を求めることが できる。

c) $a, b$ 点とも中立軸がフランジ内にある場合 $a, b$ 点とも式 (2) の降伏条件式を満足しなければならない。 式 (14), (17) および式 (15), (18) を式 (2) に代入し, 式 (8),(20) および (22) を用いると, $\left.a_{1} Q+b_{1} R+c_{1}=k^{\prime}\left\{1.00-\left(A_{N a} Q+\cos \psi_{a} R+B_{N a}\right)\right\}\right\}$ $a_{2} Q+b_{2} R+c_{2}=k^{\prime}\left\{1.00-\left(A_{N b} Q+\cos \psi_{b} R+B_{N b}\right)\right\}$

となり，この連立方程式を解いて $Q, R$ を求めることが できる。

$a, b$ 断面の降伏時における中立軸がウェブ内にあるか フランジ内にあるかは仮定した a)〜b) のおのおのの場 合について求めた $Q$ および $R$ を用いて計算した $a, b$ 点での軸方向力を $N$ とすると中立軸の位置に関する条 件式 $N / N_{y} \gtrless 1 / 1+\left(A_{F} / A_{W}\right)$ のいずれを満足するかに より判定される。もし，それが仮定したものと一致すれ ば得られた $Q$ および $R$ は真の值である。すなわち, 式 （20）より $P=Q N_{y}$ にて変形硬化荷重を求めることがで きる。

以上は図-7 のように等分布荷重と $d_{a}$ 点に集中荷重 が載荷した場合に $a$ 点に塑性ヒンジが形成し，また図一 8 のように等分布荷重と $d_{b}$ 点に集中荷重が載荷した場 合に, $b$ 点に塑性ヒンジが形成するとした場合の変形硬 化荷重である。しかし，この場合必ずしも全断面で塑性 モーメント条件を満足しているとは限らない。塑性条件 を満足するには $\psi_{a}, \psi_{b}$ のあらゆる組み合わせに対して $P$ の最小值を求めなければならない。すなわち, この $P$ の最小值が与えられた荷重位置の組み合わせに対する変 形硬化荷重である。

いま, 集中荷重はスパン中央 $C$ よりそれぞれ $\theta_{a}, \theta_{b}$ 
だけ $B$ 支点側に載荷されたと考えたが，集中荷重は移 動荷重であるから任意の位置に載荷される。したが って，荷重の移動を考慮した変形硬化荷重は $\theta_{a} ， \theta_{b}$ を $-\phi<\theta_{a}, \theta_{a}<\phi$ の範囲で変化させたあらゆる組み合わ せに対する最小値である。なお, 変形硬化荷重の計算結 果は 6.にまとめてある。

\section{5. 交番塑性荷重}

ある断面に交番塑性応力が発生し，交番塑性状態に入 ったとき，この数百回のくり返し交番塑性により部材断 面は破断する。

すなわち，ある荷重状態のある断面での最大縁応力度 を $\sigma_{\max }$ とし, 他の荷重状態での同一断面同一点での最 小縁志力度を $\sigma_{\min }$ とすると, つぎの条件を満足すると きそその断面で交番塑性破断をおこす。

$$
\sigma_{\max }-\sigma_{\min } \geqq 2 \sigma_{y}
$$

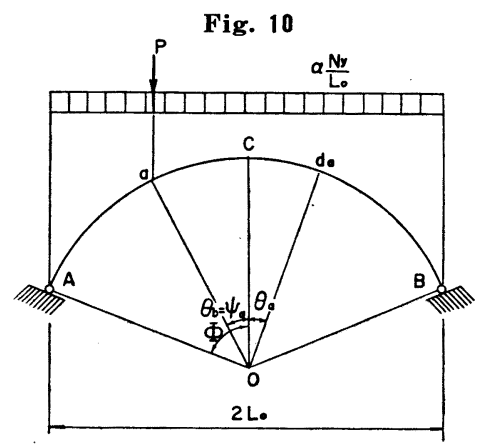

Fig. 11

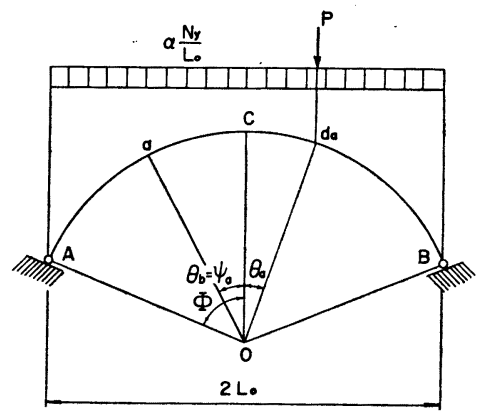

図一10 の荷重状態で $a$ 点に正の曲げモーメント $M_{1}$ が生じ, 図一11の荷重状態で負の曲げモーメント $M_{2}$ が 生じ, また, 軸方向力をそれぞれ $N_{1}, N_{2}$ とすると, 断 面 $a$ の正負の縁応力度を式（25）に代入すると，

$$
\left.\begin{array}{c}
\left|\left(M_{1}-M_{2}\right) \frac{A \cdot d}{2 I}-\left(N_{1}-N_{2}\right)\right| \geqq 2 N_{y} \\
-\left(M_{1}-M_{2}\right) \frac{A \cdot d}{2 I}-\left(N_{1}-N_{2}\right) \mid \geqq 2 N_{y}
\end{array}\right\}
$$

となる。ただし， $I$ は断面 2 次モーメントである。

$M_{1}, M_{2}, N_{1}, N_{2}$ に式 (14) および (15) を用い整理 すると, 等分布荷重による項は消去され, 式 (26) は次
式のようになる。

$$
\left.\begin{array}{l}
\left|\left(A_{M a}-A_{M b}\right) \eta-\left(A_{N a}-A_{N b}\right)\right| P \geqq 2 N_{y} \\
\left|-\left(A_{M a}-A_{M b}\right) \eta-\left(A_{N a}-A_{N b}\right)\right| P \geqq 2 N_{y}
\end{array}\right\}
$$

ただし，

$$
\eta=\frac{2\left\{\left(A_{F} / A_{W}\right)+1\right\}\left(d / d_{w}\right)^{2}}{\left.\left(\left[1+\frac{1}{2}\left\{d / d_{w}\right)-1\right\}\right]^{2}\left(A_{F} / A_{W}\right)+\frac{1}{3}\right) \delta}
$$

式 (27) を解いて得られた $P$ のうち小さい值が $a$ 点で 交番塑性破壊すると仮定した場合の交番塑性荷重であ る。 $a$ 点恃全く任意に仮定した点であるから，図一10 において $\psi_{a}$ を $0<\psi_{a}<\phi$ の範囲で変化させた場合 の $P$ の最小值が 図-10 と図-11 の荷重状態が 交互 に作用すると考えた場合の交番塑性荷重である。いま, 集中荷重はスパン中央 $C$ より $\theta_{a}$ だけ $A$ 支点側と $\theta_{b}$ だけ $B$ 支点側に載荷されたと考えたが，集中荷重は移 動荷重であるから任意の位置に載荷される。したがっ て, 荷重の移動を考慮すると, 交番塑性荷重は $\theta_{a}, \theta_{b}$ を $0<\theta_{a}, \theta_{b}<\phi$ の範囲で変化させたあらゆる組み合わせ に対する $P$ の最小值である。なお, 交番塑性荷重の計 算結果は 6. にまとめてある。

\section{6. 解析結果亡考察}

前節 3.,4.,5. で述べた方法により崩壊荷重, 変形硬 化荷重および交番塑性荷重を求めたが，以下にそれらの 計算結果を示し，あわせて考察を加えた。計算に用いた パラメーターは $d / L_{0}=0.02,0.05,0.10, d / d_{w}=1.1$, $A_{F} / A_{W}=0.1,1.5,3.0$ からなっている。ここに $d=ア$ 一チ リブ断面高さ, $L_{0}=$ 半スパン長, $d_{w}=$ アーチリブ 断面のウェブ高さ, $A_{F}=$ フランジ全断面積, $A_{W}=$ ウェ ブ断面積, また, 用いたアーチの半中心角は $\phi=10^{\circ} \sim$ $90^{\circ}$ までとし， $10^{\circ}$ ごとのピッチとした。一般に用いら れるアーチ断面では $d / d_{w}=1.10 \sim 1.14$ であると考えら れるから，ここでは $d / d_{w}=1.1$ を用いた。また $A_{F} / A_{W}$ $=0.1$ 江 $d / d_{w}=1.1$ の場合は矩形断面を表わし，また 一般に用いられる断面では $A_{F} / A_{W}=1.0 \sim 3.0$ であると 考えられるから，ここでは $A_{F} / A_{W}=1.5,3.0$ を採用し た。

等分布死荷重 $\left(w=\alpha N_{y} / L_{0}\right)$ は, $d / L_{0}=0.02,0.05$, 0.10 に対して，それぞれ， $\alpha=0.02,0.05,0.10$ の值を 用いた。

\section{（1）崩壊荷重}

a) 崩壊荷重 表一1 は単一集中荷重のみによる崩 壊荷重 (上段) と変形硬化荷重 (下段) を示したもので ある。各荷重はこれらの係数に $N_{y}\left(=A \sigma_{y}\right)$ をかけた 值となる。また, 表一2 は等分布荷重による崩壊荷重 $w_{\boldsymbol{u}}=\alpha N_{y} / L_{0}$ を, 表一3 は与えられた等分布荷重が載荷 されているとき，同時に作用する単一集中荷重による崩 
Table 1 Ultimate Load and Shake-down Load (Concentrated Loading)

$\left(\times N_{y}\right)$

\begin{tabular}{|c|c|c|c|c|c|c|c|c|c|c|}
\hline \multirow{2}{*}{$d / L_{0}$} & \multirow{2}{*}{$A_{F} / A_{W}$} & \multicolumn{9}{|c|}{$\phi$} \\
\hline & & $10^{\circ}$ & $20^{\circ}$ & $30^{\circ}$ & $40^{\circ}$ & $50^{\circ}$ & $60^{\circ}$ & $70^{\circ}$ & $80^{\circ}$ & $90^{\circ}$ \\
\hline \multirow{3}{*}{0.02} & 0.1 & $\begin{array}{l}0.0378^{*} \\
0.0363^{* *}\end{array}$ & $\begin{array}{l}0.0385 \\
0.0369\end{array}$ & $\begin{array}{l}0.0388 \\
0.0373\end{array}$ & $\begin{array}{l}0.0392 \\
0.0378\end{array}$ & $\begin{array}{l}0.0396 \\
0.0383\end{array}$ & $\begin{array}{l}0.0399 \\
0.0389\end{array}$ & $\begin{array}{l}0.0399 \\
0.0392\end{array}$ & $\begin{array}{l}0.0399 \\
0.0389\end{array}$ & $\begin{array}{l}0.0371 \\
0.036 \mathrm{~S}\end{array}$ \\
\hline & 1.5 & $\begin{array}{l}0.0548 \\
0.0528\end{array}$ & $\begin{array}{l}0.0574 \\
0.0551\end{array}$ & $\begin{array}{l}0.0583 \\
0.0560\end{array}$ & $\begin{array}{l}0.0590 \\
0.0568\end{array}$ & $\begin{array}{l}0.0597 \\
0.0576\end{array}$ & $\begin{array}{l}0.0602 \\
0.0585\end{array}$ & $\begin{array}{l}0.0600 \\
0.0591\end{array}$ & $\begin{array}{l}0.0588 \\
0.0586\end{array}$ & $\begin{array}{l}0.0559 \\
0.0557\end{array}$ \\
\hline & 3.0 & $\begin{array}{l}0.0579 \\
0.0558\end{array}$ & $\begin{array}{l}0.0624 \\
0.0599\end{array}$ & $\begin{array}{l}0.0637 \\
0.0612\end{array}$ & $\begin{array}{l}0.0646 \\
0.0622\end{array}$ & $\begin{array}{l}0.0654 \\
0.0632\end{array}$ & $\begin{array}{l}0.0660 \\
0.0642\end{array}$ & $\begin{array}{l}0.0659 \\
0.0648\end{array}$ & $\begin{array}{l}0.0646 \\
0.0643\end{array}$ & $\begin{array}{l}0.0614 \\
0.0612\end{array}$ \\
\hline \multirow{3}{*}{0.05} & 0.1 & $0.08 \overline{4}$ & $\begin{array}{l}0.1269 \\
0.0903\end{array}$ & $\begin{array}{l}0.1324 \\
0.0922\end{array}$ & $\begin{array}{l}0.1353 \\
0.0937\end{array}$ & $\begin{array}{l}0.1375 \\
0.0952\end{array}$ & $\begin{array}{l}0.1390 \\
0.0967\end{array}$ & $\begin{array}{l}0.1391 \\
0.0977\end{array}$ & $\begin{array}{l}0.1365 \\
0.0970\end{array}$ & $\begin{array}{l}0.1295 \\
0.0922\end{array}$ \\
\hline & 1.5 & $0.10 \overline{3}$ & $\begin{array}{l}0.1330 \\
0.1284\end{array}$ & $\begin{array}{l}0.1402 \\
0.1349\end{array}$ & $\begin{array}{l}0.1439 \\
0.1386\end{array}$ & $\begin{array}{l}0.1465 \\
0.1415\end{array}$ & $\begin{array}{l}0.1483 \\
0.1442\end{array}$ & $\begin{array}{l}0.1485 \\
0.1460\end{array}$ & $\begin{array}{l}0.1458 \\
0.1452\end{array}$ & $\begin{array}{l}0.1388 \\
0.1386\end{array}$ \\
\hline & 3.0 & - & - & $\begin{array}{l}0.1492 \\
0.1436\end{array}$ & $\begin{array}{l}0.1548 \\
0.1491\end{array}$ & $\begin{array}{l}0.1586 \\
0.1531\end{array}$ & $\begin{array}{l}0.1610 \\
0.1564\end{array}$ & $\begin{array}{l}0.1616 \\
0.1588\end{array}$ & $\begin{array}{l}0.1591 \\
0.1583\end{array}$ & $\begin{array}{l}0.1518 \\
0.1516\end{array}$ \\
\hline \multirow{3}{*}{0.10} & 0.1 & $\begin{array}{l}0.1413 \\
0.1386\end{array}$ & $\begin{array}{l}0.1739 \\
0.1688\end{array}$ & $\begin{array}{l}0.1844 \\
0.1779\end{array}$ & $\begin{array}{l}0.1898 \\
0.1830\end{array}$ & $\begin{array}{l}0.1935 \\
0.1870\end{array}$ & $\begin{array}{l}0.1960 \\
0.1906\end{array}$ & $\begin{array}{l}0.1963 \\
0.1930\end{array}$ & $\begin{array}{l}0.1929 \\
0.1921\end{array}$ & $\begin{array}{l}0.1838 \\
0.1835\end{array}$ \\
\hline & 1.5 & $\overline{-}$ & $0.21 \overline{34}$ & $\begin{array}{l}0.2494 \\
0.2419\end{array}$ & $\begin{array}{l}0.2659 \\
0.2569\end{array}$ & $\begin{array}{l}0.2762 \\
0.2669\end{array}$ & $\begin{array}{l}0.2830 \\
0.2748\end{array}$ & $\begin{array}{l}0.2861 \\
0.2804\end{array}$ & $\begin{array}{l}0.2834 \\
0.2815\end{array}$ & $\begin{array}{l}0.2720 \\
0.2719\end{array}$ \\
\hline & 3.0 & - & - & - & 0.2641 & $0.27 \overline{8}$ & $\begin{array}{l}0.2982 \\
0.2889\end{array}$ & $\begin{array}{l}0.3039 \\
0.2969\end{array}$ & $\begin{array}{l}0.3033 \\
0.3003\end{array}$ & $\begin{array}{l}0.2931 \\
0.2931\end{array}$ \\
\hline
\end{tabular}

* Upper Lines indicate for Ultemate Load

** Lower Lines indicate for shake-down Load

Table 2 Ultimate Load (Uniform Loading)

$\left(\times N_{y} / L_{0}\right)$

\begin{tabular}{|c|c|c|c|c|c|c|c|c|c|}
\hline \multirow{2}{*}{$d / L_{0}$} & \multirow{2}{*}{$A_{F} / A_{W}$} & \multicolumn{8}{|c|}{$\phi$} \\
\hline & & $20^{\circ}$ & $30^{\circ}$ & $40^{\circ}$ & $50^{\circ}$ & $60^{\circ}$ & $70^{\circ}$ & $80^{\circ}$ & $90^{\circ}$ \\
\hline \multirow{3}{*}{0.02} & 0.1 & 0.3169 & 0.3819 & 0.3781 & 0.2455 & 0.1662 & 0.1174 & 0.0823 & 0.0581 \\
\hline & 1.5 & - & - & - & - & 0.2416 & 0.1691 & 0.1226 & 0.0872 \\
\hline & 3.0 & - & - & - & - & - & 0.1837 & 0.1330 & 0.0952 \\
\hline \multirow{3}{*}{0.05} & 0.1 & - & 0.4499 & 0.4909 & 0.4490 & 0.3734 & 0.2757 & 0.2003 & 0.1434 \\
\hline & 1.5 & - & - & - & - & - & 0.3644 & 0.2817 & 0.2091 \\
\hline & 3.0 & - & - & - & - & - & - & - & 0.2217 \\
\hline \multirow{3}{*}{0.10} & 0.1 & - & 0.4708 & 0.5650 & 0.5929 & 0.5587 & 0.4709 & 0.3677 & 0.2748 \\
\hline & 1.5 & - & - & - & - & - & - & - & 0.3705 \\
\hline & 3.0 & - & - & - & - & - & - & - & - \\
\hline
\end{tabular}

Table 3 Ultimate Load and Shake-down Load (Combined Loading)

$\left(\times N_{y}\right)$

\begin{tabular}{|c|c|c|c|c|c|c|c|c|c|c|}
\hline \multirow{2}{*}{$d / L_{J}$} & \multirow{2}{*}{$\alpha$} & \multirow{2}{*}{$A_{F} / A_{W}$} & \multicolumn{8}{|c|}{$\phi$} \\
\hline & & & $20^{\circ}$ & $30^{\circ}$ & $40^{\circ}$ & $50^{\circ}$ & $60^{\circ}$ & $70^{\circ}$ & $80^{\circ}$ & $90^{\circ}$ \\
\hline \multirow{3}{*}{0.02} & \multirow{3}{*}{0.02} & 0.1 & $\begin{array}{l}0.0382^{*} \\
0.0378^{* *}\end{array}$ & $\begin{array}{l}0.0390 \\
0.0376\end{array}$ & $\begin{array}{l}0.0396 \\
0.0383\end{array}$ & $\begin{array}{l}0.0399 \\
0.0388\end{array}$ & $\begin{array}{l}0.0392 \\
0.0388\end{array}$ & $\begin{array}{l}0.0371 \\
0.0371\end{array}$ & $\begin{array}{l}0.0329 \\
0.0323\end{array}$ & $\begin{array}{l}0.0265 \\
0.0260\end{array}$ \\
\hline & & 1.5 & $\begin{array}{r}0.0563 \\
-\end{array}$ & $\begin{array}{l}0.0581 \\
0.0562\end{array}$ & $\begin{array}{l}0.0592 \\
0.0571\end{array}$ & $\begin{array}{l}0.0599 \\
0.0581\end{array}$ & $\begin{array}{l}0.0597 \\
0.0586\end{array}$ & $\begin{array}{l}0.0577 \\
0.0576\end{array}$ & $\begin{array}{l}0.0533 \\
0.0528\end{array}$ & $\begin{array}{l}0.0460 \\
0.0453\end{array}$ \\
\hline & & 3.0 & 0.0604 & $\begin{array}{l}0.0631 \\
0.0610\end{array}$ & $\begin{array}{l}0.0646 \\
0.0623\end{array}$ & $\begin{array}{l}0.0655 \\
0.0635\end{array}$ & $\begin{array}{l}0.0654 \\
0.0642\end{array}$ & $\begin{array}{l}0.0636 \\
0.0634\end{array}$ & $\begin{array}{l}0.0591 \\
0.0587\end{array}$ & $\begin{array}{l}0.0516 \\
0.0508\end{array}$ \\
\hline \multirow{3}{*}{0.05} & \multirow{3}{*}{0.05} & 0.1 & 0.0883 & $\begin{array}{l}0.0939 \\
0.0919\end{array}$ & $\begin{array}{l}0.0968 \\
0.0938\end{array}$ & $\begin{array}{l}0.0981 \\
0.0956\end{array}$ & $\begin{array}{l}0.0969 \\
0.0959\end{array}$ & $\begin{array}{l}0.0918 \\
0.0918\end{array}$ & $\begin{array}{l}0.0815 \\
0.0801\end{array}$ & $\begin{array}{l}0.0659 \\
0.0647\end{array}$ \\
\hline & & 1.5 & $\begin{array}{r}0.1179 \\
-\end{array}$ & $\begin{array}{l}0.1327 \\
0.1313\end{array}$ & $\begin{array}{l}0.1399 \\
0.1357\end{array}$ & $\begin{array}{l}0.1439 \\
0.1397\end{array}$ & $\begin{array}{l}0.1448 \\
0.1422\end{array}$ & $\begin{array}{l}0.1410 \\
0.1406\end{array}$ & $\begin{array}{l}0.1306 \\
0.1299\end{array}$ & $\begin{array}{l}0.1133 \\
0.1118\end{array}$ \\
\hline & & 3.0 & - & - & $\begin{array}{l}0.1476 \\
0.1432\end{array}$ & $\begin{array}{l}0.1536 \\
0.1490\end{array}$ & $\begin{array}{l}0.1559 \\
0.1527\end{array}$ & $\begin{array}{l}0.1531 \\
0.1523\end{array}$ & $\begin{array}{l}0.1435 \\
0.1430\end{array}$ & $\begin{array}{l}0.1260 \\
0.1245\end{array}$ \\
\hline \multirow{3}{*}{0.10} & \multirow{3}{*}{0.10} & 0.1 & $\begin{array}{r}0.1375 \\
-\end{array}$ & $\begin{array}{l}0.1654 \\
0.1654\end{array}$ & $\begin{array}{l}0.1788 \\
0.1747\end{array}$ & $\begin{array}{l}0.1856 \\
0.1811\end{array}$ & $\begin{array}{l}0.1859 \\
0.1837\end{array}$ & $\begin{array}{l}0.1776 \\
0.1776\end{array}$ & $\begin{array}{l}0.1586 \\
0.1564\end{array}$ & $\begin{array}{l}0.1287 \\
0.1267\end{array}$ \\
\hline & & 1.5 & - & - & $\begin{array}{l}0.2353 \\
0.2313\end{array}$ & $\begin{array}{r}0.2537 \\
0.2468\end{array}$ & $\begin{array}{l}0.2628 \\
0.2573\end{array}$ & $\begin{array}{l}0.2613 \\
0.2597\end{array}$ & $\begin{array}{l}0.2460 \\
0.2455\end{array}$ & $\begin{array}{l}0.2155 \\
0.2137\end{array}$ \\
\hline & & 3.0 & $\overline{-}$ & $\overline{-}$ & $\overline{-}$ & - & $\overline{-}$ & $\overline{-}$ & $\begin{array}{l}0.2608 \\
0.2608\end{array}$ & $\begin{array}{l}0.2328 \\
0.2318\end{array}$ \\
\hline
\end{tabular}

* Upper Lines indicate for Ultimate Load

** Lower Lines indicate for shake-down Load

壊荷重 (上段) と変形硬化荷重（下段）を示したもので ある。

図一12,13 および 14 は 表一1,2 および 3 の崩壊荷重 を図示したもので, 縦軸に崩壊荷重を, 横軸にアーチの 半中心角をとってある。図中点線は軸方向力を無規して 計算した值を示している。これらの図から明らかなよう
に, $\phi=80^{\circ} \sim 90^{\circ}$ 付近では軸方向力の影響は少なく, 特 に $d / L_{0}, A_{F} / A_{W}$ が小さい場合はその影響はほとんどみ とめられない。しかし， $\phi$ の值が小さく, 特に $d / L_{0}$, $A_{F} / A_{W}$ の值が大きい場合はその影響はもはや無視でき なくなり, ことに, 等分布荷重のみによる崩壊荷重, ま たは等分布荷重と集中荷重との組み合わせ荷重の場合に 
Fig. 12 Ultimate Load (Concentrated Loading)

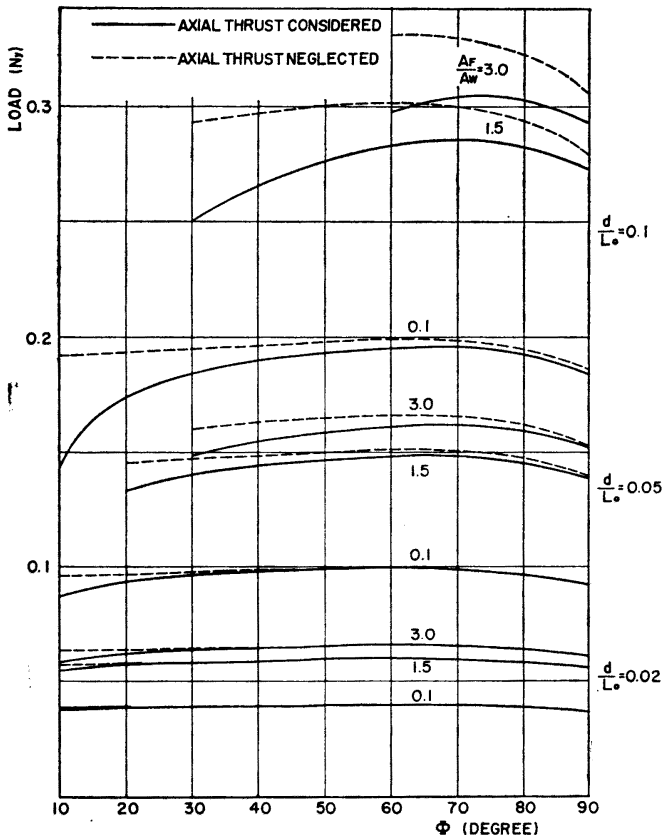

Fig. 13 Ultimate Load (Uniform Loading)

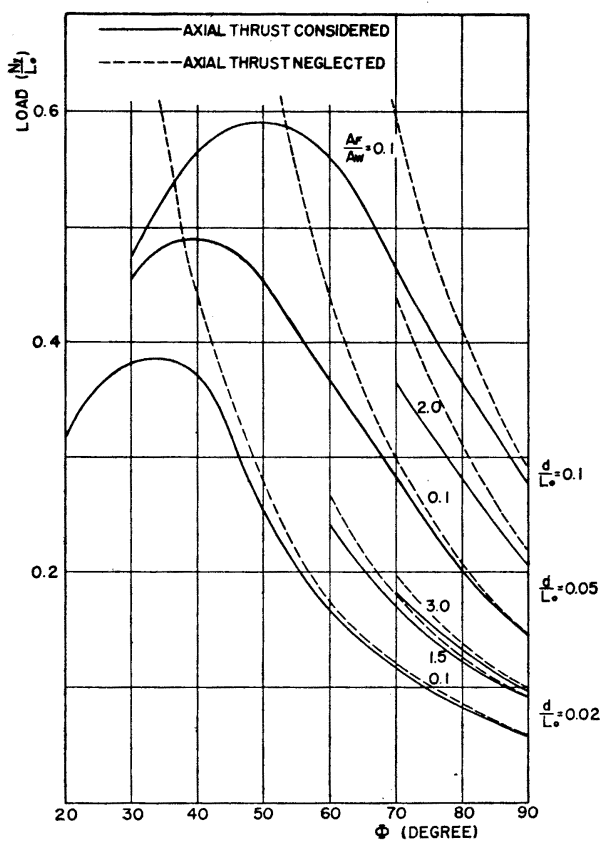

はその影響はきわめて大きい。なお，図には崩壊時にお ける中立軸の位置がウェブ内にある場合のみを示してあ る。

b）塑性ヒンジ点の曲げモーメントと軸方向力 図 -15〜図一20 は単一集中荷重, 等分布荷重または組み 合わせ荷重による崩壊時の塑性ヒンジ位置 $a$ および $b$ の 曲げモーメントおよび軸方向力の大きさを図示したもの である。これによっても，фの減少とともに軸方向力が
Fig. 14 Ultimate Load (Combined Loading)

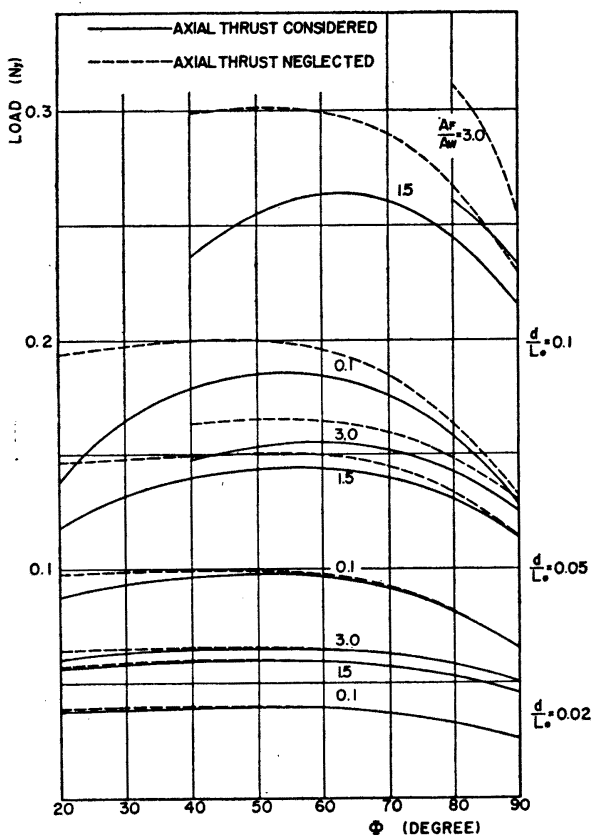

Fig. 15 Critical Bending Moment and Axial Thrust at Hinge " $a$ " under Concentrated Loading.

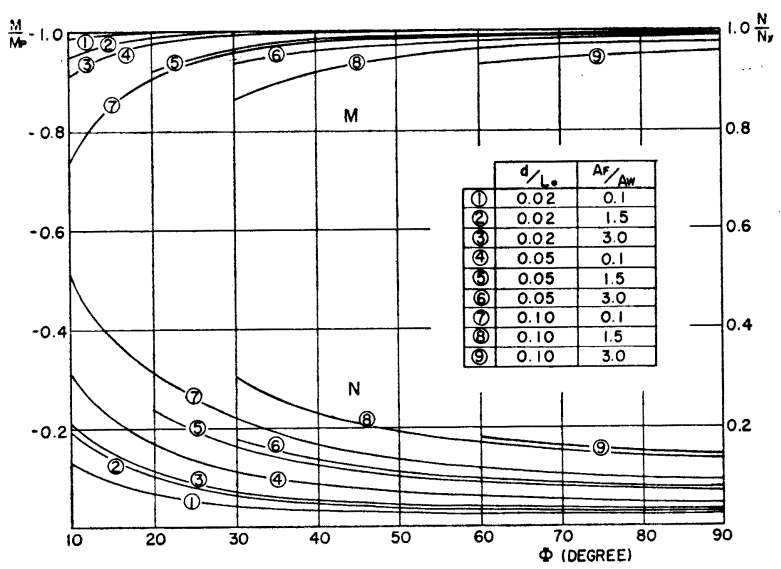

Fig. 16 Critical Bending Moment and Axial Thrust at Hinge " $b$ " Concentrated Loading.

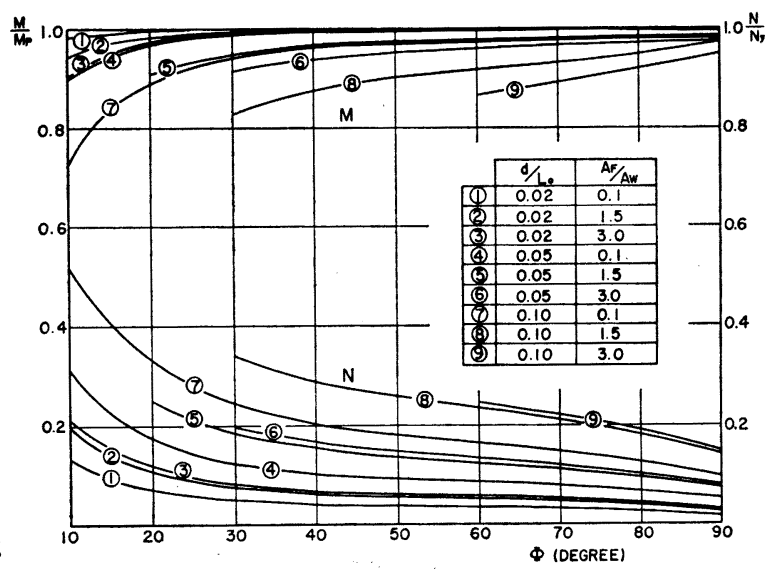


Fig. 17 Critical Bending Moment and Axial Thrust at Hinge " $a$ " under Uniform Loading.

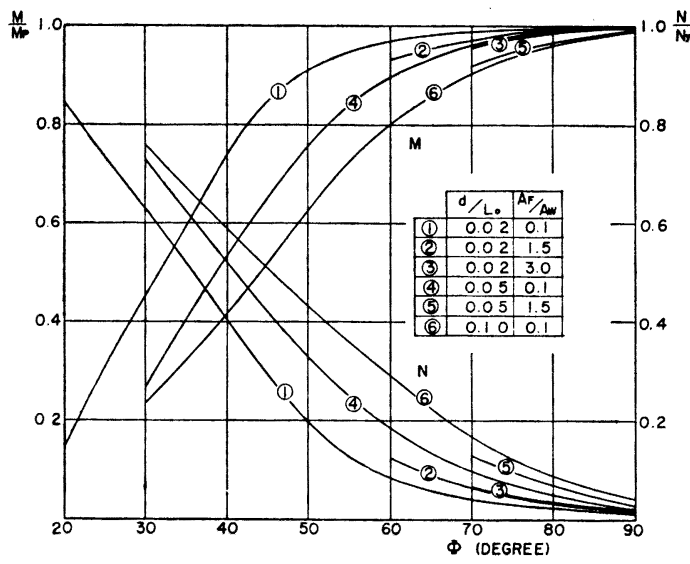

Fig. 18 Critical Bending Moment and Axial Thrust at Hinge " $b$ " under Uniform Loading.

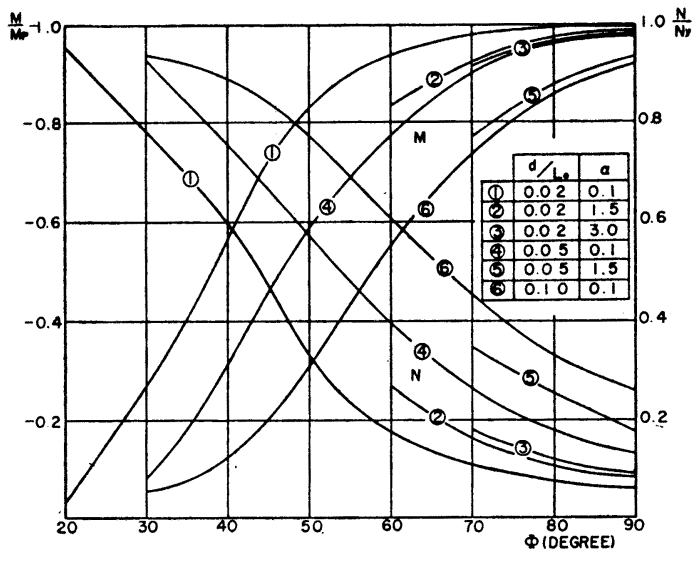

増大し, 曲げモーメントが減少する様子がわかる。特に 等分布荷重のみの場合にその傾向がいちじるしい。

c) 塑性ヒンジ位置 表一4,5 および 6 は単一集中 荷重, 等分布荷重, 組み合わせ荷重によるそれぞれの崩
Fig. 19 Critical Bending Moment and Axial Thrust at Hinge " $a$ " Under Combined Loading.

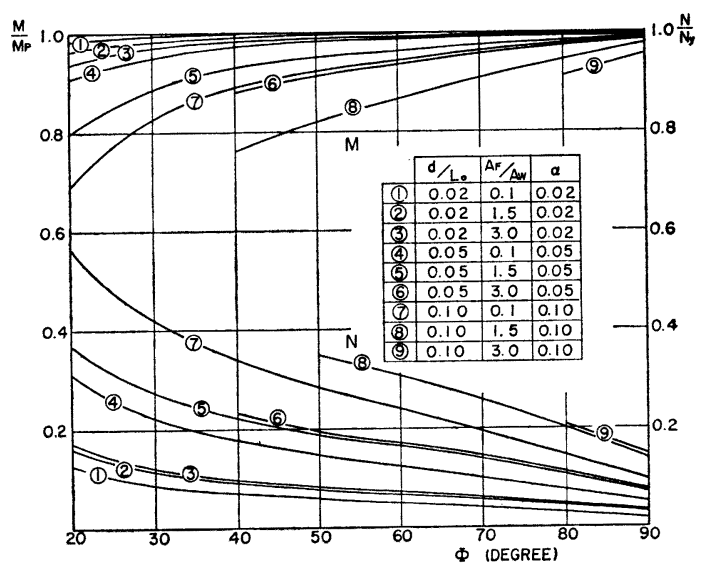

Fig. 20 Critical Bending Moment and Axial Thrust at Hinge " $b$ " Under Combined Loading.

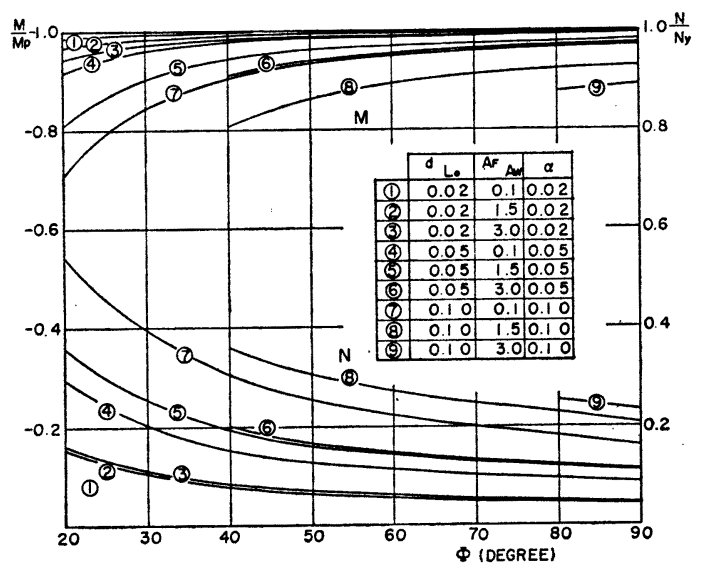

壊時の塑性ヒンジの位置を示したもので，塑性ヒンジの 位置は $d / L_{0}, A_{F} / A_{W}$ によって大きく変化することはな く，ほぼ一定の位置に生ずる。これらの塑性ヒンジの位 置は軸方向力を無視して求めた崩壊時の塑性ヒンジの位

Table 4 Locations of Plastic Hinge Formation under Ultimate Load (Concentrated Loading) (DEGREE)

\begin{tabular}{|c|c|c|c|c|c|c|c|c|c|c|c|}
\hline \multirow{2}{*}{$d / L_{0}$} & \multirow{2}{*}{$A_{F} / A_{W}$} & \multirow{2}{*}{$\psi$} & \multicolumn{9}{|c|}{$\phi$} \\
\hline & & & $10^{\circ}$ & $20^{\circ}$ & $30^{\circ}$ & $40^{\circ}$ & $50^{\circ}$ & $60^{\circ}$ & $70^{\circ}$ & $80^{\circ}$ & $90^{\circ}$ \\
\hline \multirow{3}{*}{0.02} & 0.1 & $\begin{array}{l}a \\
b\end{array}$ & $\begin{array}{l}5.81 \\
3.45\end{array}$ & $\begin{array}{r}11.68 \\
6.89\end{array}$ & $\begin{array}{l}16.92 \\
10.62\end{array}$ & $\begin{array}{l}21.50 \\
14.65\end{array}$ & $\begin{array}{l}24.88 \\
19.21\end{array}$ & $\begin{array}{l}26.55 \\
24.51\end{array}$ & $\begin{array}{l}25.80 \\
30.81\end{array}$ & $\begin{array}{l}23.21 \\
37.88\end{array}$ & $\begin{array}{l}17.23 \\
46.30\end{array}$ \\
\hline & 1.5 & $\begin{array}{l}a \\
b\end{array}$ & $\begin{array}{l}5.71 \\
3.49\end{array}$ & $\begin{array}{r}11.52 \\
6.96\end{array}$ & $\begin{array}{l}16.88 \\
10.63\end{array}$ & $\begin{array}{l}21.50 \\
14.64\end{array}$ & $\begin{array}{l}24.88 \\
19.21\end{array}$ & $\begin{array}{l}26.49 \\
24.53\end{array}$ & $\begin{array}{l}25.80 \\
30.81\end{array}$ & $\begin{array}{l}23.21 \\
37.87\end{array}$ & $\begin{array}{l}17.23 \\
46.29\end{array}$ \\
\hline & 3.0 & $\begin{array}{l}a \\
b\end{array}$ & $\begin{array}{l}5.52 \\
3.57\end{array}$ & $\begin{array}{r}11.52 \\
6.96\end{array}$ & $\begin{array}{l}16.88 \\
10.63\end{array}$ & $\begin{array}{l}21.50 \\
14.64\end{array}$ & $\begin{array}{l}24.88 \\
19.20\end{array}$ & $\begin{array}{l}26.49 \\
24.52\end{array}$ & $\begin{array}{l}25.80 \\
30.81\end{array}$ & $\begin{array}{l}23.21 \\
37.87\end{array}$ & $\begin{array}{l}17.14 \\
46.33\end{array}$ \\
\hline \multirow{3}{*}{0.05} & 0.1 & $\begin{array}{l}a \\
b\end{array}$ & $\begin{array}{l}5.46 \\
3.60\end{array}$ & $\begin{array}{r}11.39 \\
7.01\end{array}$ & $\begin{array}{l}16.80 \\
10.66\end{array}$ & $\begin{array}{l}21.40 \\
14.68\end{array}$ & $\begin{array}{l}24.88 \\
19.20\end{array}$ & $\begin{array}{l}26.49 \\
24.52\end{array}$ & $\begin{array}{l}25.80 \\
30.80\end{array}$ & $\begin{array}{l}23.21 \\
37.87\end{array}$ & $\begin{array}{l}17.14 \\
46.33\end{array}$ \\
\hline & 1.5 & $\begin{array}{l}a \\
b\end{array}$ & $\overline{-}$ & $\begin{array}{r}10.87 \\
7.20\end{array}$ & $\begin{array}{l}16.51 \\
10.75\end{array}$ & $\begin{array}{l}21.30 \\
14.69\end{array}$ & $\begin{array}{l}24.75 \\
19.21\end{array}$ & $\begin{array}{l}26.46 \\
24.49\end{array}$ & $\begin{array}{l}25.80 \\
30.76\end{array}$ & $\begin{array}{l}23.21 \\
37.84\end{array}$ & $\begin{array}{l}17.14 \\
46.33\end{array}$ \\
\hline & 3.0 & $\begin{array}{l}a \\
b\end{array}$ & $=$ & $\overline{-}$ & $\begin{array}{l}16.13 \\
10.89\end{array}$ & $\begin{array}{l}21.04 \\
14.76\end{array}$ & $\begin{array}{l}24.50 \\
19.28\end{array}$ & $\begin{array}{l}26.40 \\
24.47\end{array}$ & $\begin{array}{l}25.76 \\
30.74\end{array}$ & $\begin{array}{l}23.21 \\
37.82\end{array}$ & $\begin{array}{l}17.14 \\
46.32\end{array}$ \\
\hline \multirow{3}{*}{0.10} & 0.1 & $\begin{array}{l}a \\
b\end{array}$ & $\begin{array}{l}5.32 \\
3.64\end{array}$ & $\begin{array}{r}10.75 \\
7.25\end{array}$ & $\begin{array}{l}16.40 \\
10.80\end{array}$ & $\begin{array}{l}21.09 \\
14.76\end{array}$ & $\begin{array}{l}24.75 \\
19.20\end{array}$ & $\begin{array}{l}26.46 \\
24.48\end{array}$ & $\begin{array}{l}25.80 \\
30.76\end{array}$ & $\begin{array}{l}23.21 \\
37.84\end{array}$ & $\begin{array}{l}17.14 \\
46.33\end{array}$ \\
\hline & 1.5 & $\begin{array}{l}a \\
b\end{array}$ & $=$ & $\overline{-}$ & $\begin{array}{l}15.20 \\
11.22\end{array}$ & $\begin{array}{l}20.40 \\
14.94\end{array}$ & $\begin{array}{l}24.30 \\
19.24\end{array}$ & $\begin{array}{l}26.25 \\
24.41\end{array}$ & $\begin{array}{l}25.76 \\
30.63\end{array}$ & $\begin{array}{l}23.19 \\
37.75\end{array}$ & $\begin{array}{l}17.00 \\
46.37\end{array}$ \\
\hline & 3.0 & $\begin{array}{l}a \\
b\end{array}$ & - & - & - & - & - & $\begin{array}{l}26.08 \\
24.33\end{array}$ & $\begin{array}{l}25.80 \\
30.48\end{array}$ & $\begin{array}{l}22.69 \\
38.04\end{array}$ & $\begin{array}{l}16.91 \\
46.39\end{array}$ \\
\hline
\end{tabular}


Table 5 Location of Plastic Hinge Formation under Ultimate Load (Uniform Loading)

(DEGREE)

\begin{tabular}{|c|c|c|c|c|c|c|c|c|c|}
\hline \multirow{2}{*}{$d / L_{0}$} & \multirow{2}{*}{$A_{F} / A_{W}$} & \multicolumn{8}{|c|}{$\phi$} \\
\hline & & $20^{\circ}$ & $30^{\circ}$ & $40^{\circ}$ & $50^{\circ}$ & $60^{\circ}$ & $70^{\circ}$ & $80^{\circ}$ & $90^{\circ}$ \\
\hline \multirow{3}{*}{0.02} & 0.1 & 19.52 & 27.48 & 36.89 & 41.79 & 47.38 & 53.36 & 59.93 & 66.50 \\
\hline & 1.5 & - & - & - & - & 49.77 & 50.15 & 58.00 & 64.42 \\
\hline & 3.0 & - & - & - & 一 & - & 53.67 & 58.05 & 66.86 \\
\hline \multirow{3}{*}{0.05} & 0.1 & - & 28.58 & 35.50 & 41.67 & 50.08 & 52.03 & 57.84 & 67.05 \\
\hline & 1.5 & - & - & - & - & - & 52.51 & 58.82 & 67.57 \\
\hline & 3.0 & - & - & - & - & - & - & - & 65.55 \\
\hline \multirow{3}{*}{0.10} & 0.1 & - & 26.90 & 36.92 & 43.55 & 49.36 & 54.55 & 59.47 & 67.63 \\
\hline & 1.5 & - & - & - & - & - & - & - & 66.01 \\
\hline & 3.0 & - & - & - & - & - & - & - & - \\
\hline
\end{tabular}

Table 6 Location of Plastic Hinge Formation under Ultimate Load (Combined Loading) (DEGREE)

\begin{tabular}{|c|c|c|c|c|c|c|c|c|c|c|c|}
\hline \multirow{2}{*}{$d / L_{0}$} & \multirow{2}{*}{$\alpha$} & \multirow{2}{*}{$A_{F} / A_{W}$} & \multirow{2}{*}{$\psi$} & \multicolumn{8}{|c|}{$\phi$} \\
\hline & & & & $20^{\circ}$ & $30^{\circ}$ & $40^{\circ}$ & $50^{\circ}$ & $60^{\circ}$ & $70^{\circ}$ & $80^{\circ}$ & $90^{\circ}$ \\
\hline \multirow{3}{*}{0.02} & \multirow{3}{*}{0.02} & 0.1 & $\begin{array}{l}a \\
b\end{array}$ & $\begin{array}{r}11.48 \\
7.20\end{array}$ & $\begin{array}{l}16.50 \\
11.43\end{array}$ & $\begin{array}{l}20.38 \\
16.62\end{array}$ & $\begin{array}{l}22.17 \\
22.98\end{array}$ & $\begin{array}{l}21.43 \\
30.80\end{array}$ & $\begin{array}{l}18.10 \\
39.37\end{array}$ & $\begin{array}{l}13.36 \\
48.54\end{array}$ & $\begin{array}{r}8.00 \\
57.59\end{array}$ \\
\hline & & 1.5 & $\begin{array}{l}a \\
b\end{array}$ & $\begin{array}{r}11.31 \\
7.43\end{array}$ & $\begin{array}{l}16.59 \\
11.00\end{array}$ & $\begin{array}{l}20.73 \\
15.80\end{array}$ & $\begin{array}{l}23.04 \\
21.67\end{array}$ & $\begin{array}{l}23.00 \\
28.70\end{array}$ & $\begin{array}{l}20.35 \\
36.92\end{array}$ & $\begin{array}{l}15.70 \\
45.97\end{array}$ & $\begin{array}{l}10.36 \\
54.97\end{array}$ \\
\hline & & 3.0 & $\begin{array}{l}a \\
b\end{array}$ & $\begin{array}{r}11.19 \\
7.43\end{array}$ & $\begin{array}{l}16.50 \\
11.00\end{array}$ & $\begin{array}{l}20.73 \\
15.69\end{array}$ & $\begin{array}{l}23.19 \\
21.38\end{array}$ & $\begin{array}{l}23.17 \\
28.35\end{array}$ & $\begin{array}{l}20.76 \\
36.51\end{array}$ & $\begin{array}{l}16.16 \\
45.27\end{array}$ & $\begin{array}{l}10.63 \\
54.18\end{array}$ \\
\hline \multirow{3}{*}{0.05} & \multirow{3}{*}{0.05} & 0.1 & $\begin{array}{l}a \\
b\end{array}$ & $\begin{array}{r}11.07 \\
7.43\end{array}$ & $\begin{array}{l}16.24 \\
11.61\end{array}$ & $\begin{array}{l}20.15 \\
16.73\end{array}$ & $\begin{array}{l}21.87 \\
23.27\end{array}$ & $\begin{array}{l}21.25 \\
30.80\end{array}$ & $\begin{array}{l}17.90 \\
39.57\end{array}$ & $\begin{array}{l}13.13 \\
48.54\end{array}$ & $\begin{array}{r}8.00 \\
57.60\end{array}$ \\
\hline & & 1.5 & $\begin{array}{l}a \\
b\end{array}$ & $\begin{array}{r}10.49 \\
7.43\end{array}$ & $\begin{array}{l}15.97 \\
11.08\end{array}$ & $\begin{array}{l}20.15 \\
16.73\end{array}$ & $\begin{array}{l}22.75 \\
21.67\end{array}$ & $\begin{array}{l}22.83 \\
28.70\end{array}$ & $\begin{array}{l}20.14 \\
37.53\end{array}$ & $\begin{array}{l}15.46 \\
46.20\end{array}$ & $\begin{array}{r}9.84 \\
55.23\end{array}$ \\
\hline & & 3.0 & $\begin{array}{l}a \\
b\end{array}$ & - & $=$ & $\begin{array}{l}19.92 \\
16.50\end{array}$ & $\begin{array}{l}22.60 \\
22.25\end{array}$ & $\begin{array}{l}23.17 \\
29.05\end{array}$ & $\begin{array}{l}20.35 \\
37.12\end{array}$ & $\begin{array}{l}15.70 \\
45.97\end{array}$ & $\begin{array}{l}10.10 \\
54.97\end{array}$ \\
\hline \multirow{3}{*}{0.10} & \multirow{3}{*}{0.10} & 0.1 & $\begin{array}{l}a \\
b\end{array}$ & $\begin{array}{l}9.97 \\
7.96\end{array}$ & $\begin{array}{l}19.45 \\
15.97\end{array}$ & $\begin{array}{l}19.45 \\
16.97\end{array}$ & $\begin{array}{l}21.14 \\
23.47\end{array}$ & $\begin{array}{l}20.77 \\
31.38\end{array}$ & $\begin{array}{l}17.37 \\
40.19\end{array}$ & $\begin{array}{l}12.66 \\
49.00\end{array}$ & $\begin{array}{r}7.22 \\
58.12\end{array}$ \\
\hline & & 1.5 & $\begin{array}{l}a \\
b\end{array}$ & - & - & $\begin{array}{l}18.87 \\
16.62\end{array}$ & $\begin{array}{l}21.73 \\
22.98\end{array}$ & $\begin{array}{l}21.73 \\
30.10\end{array}$ & $\begin{array}{l}19.12 \\
37.94\end{array}$ & $\begin{array}{l}14.53 \\
46.90\end{array}$ & $\begin{array}{r}8.79 \\
55.76\end{array}$ \\
\hline & & 3.0 & $\begin{array}{l}a \\
b\end{array}$ & - & - & - & $\overline{-}$ & - & - & $\begin{array}{l}14.30 \\
47.37\end{array}$ & $\begin{array}{r}8.79 \\
56.02\end{array}$ \\
\hline
\end{tabular}

置との相違は半スパン長 $L_{0}$ の数 \% 以内である。

\section{（2）変形硬化荷重}

a）変形硬化荷重単一集中荷重および組み合わせ 荷重による変形硬化荷重は 表一1 および 表一3 の下段 に示されている。

b) 塑性ヒンジ点での曲げモーメントと軸方向力 図一21 および 図一22 は組み合わせ荷重による変形硬化 荷重の塑性ヒンジ形成時のヒンジ $a$ および $b$ での曲げ

Fig. 21 Critical Bending Moment and Axial Thrust at Hinge " $a$ " Under Shake-down Loading (Cambined)

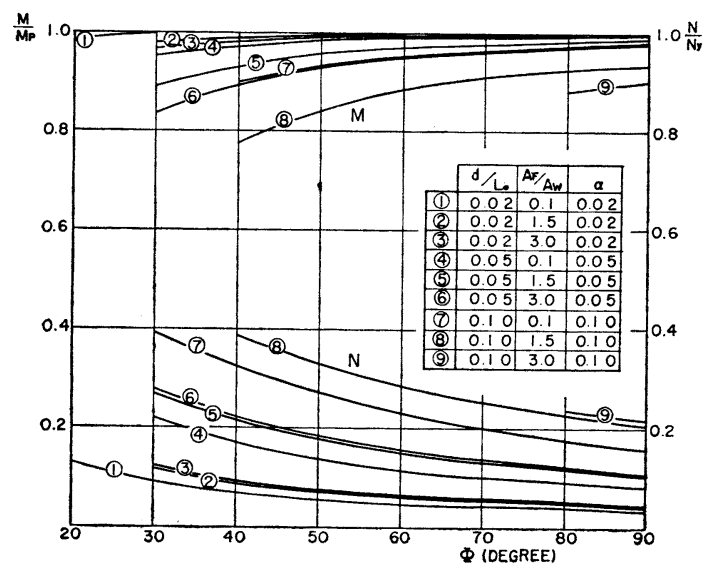

モーメントおよび軸方向力を示したものである。これは 図一19 および 図一20 の崩壊時におけるものとほぼ同一 の傾向を示している。図一23 および図一24 は変形硬化 荷重による塑性ヒンジ形成時のヒンジ $a$ の残留曲げモー メントおよび残留軸方向力を図示したものであり, 図一 25 および図一26 はヒンジbのものを図示してある。こ れらの図からわかるように残留曲げモーメントの值は $\phi$ $=50^{\circ} \sim 90^{\circ}$ ではほぼ一定でそれより $\phi$ が減少すると急激

Fig. 22 Critical Bending Moment and Axial Thrust at Hinge " $a$ " Under Shake-down Loading (Combined)

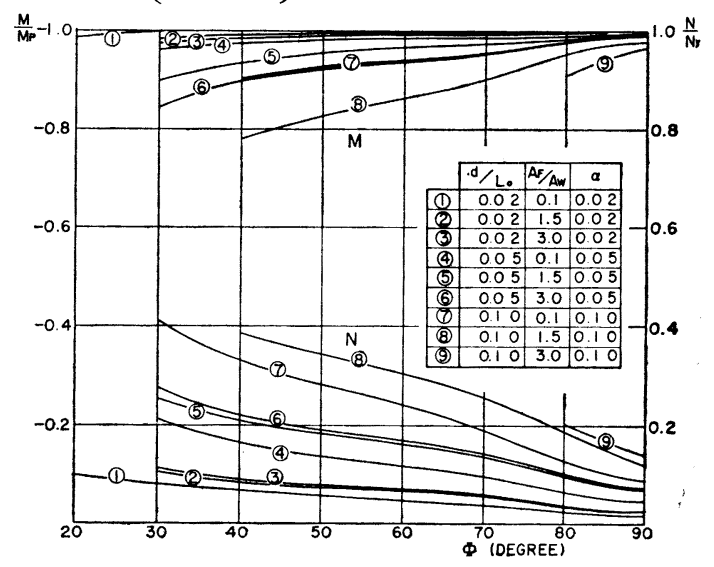


Fig. 23 Residual Moment at Hinge " $a$ ".

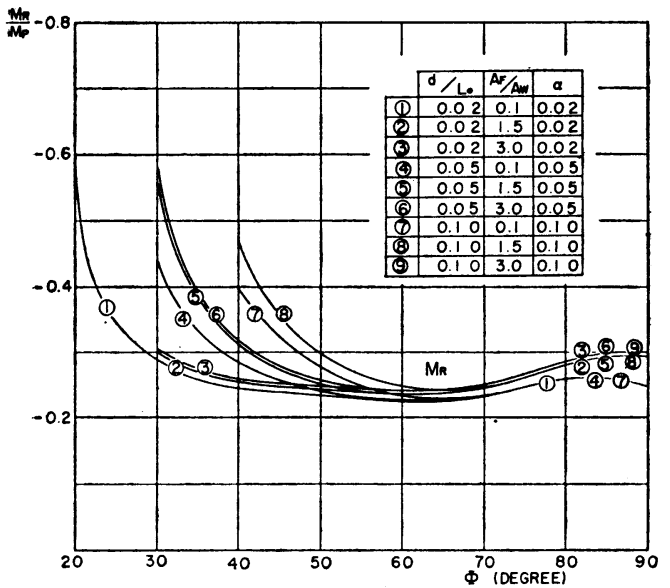

Fig. 24 Residual Thrust at Hinge " $a$ ".

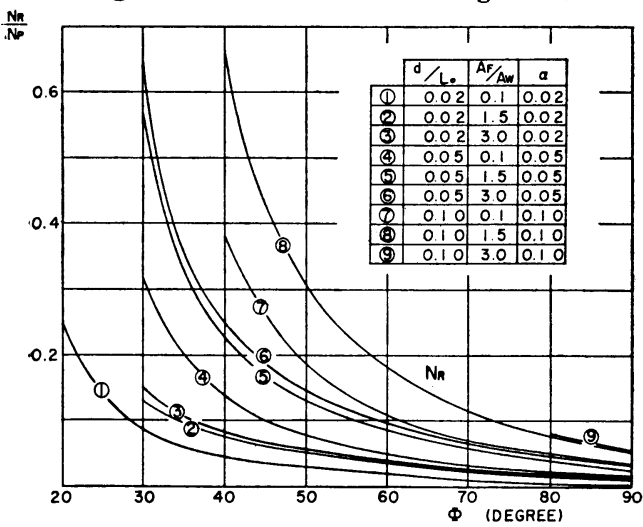

Fig. 25 Residual Moment at Hinge " $b$ ".

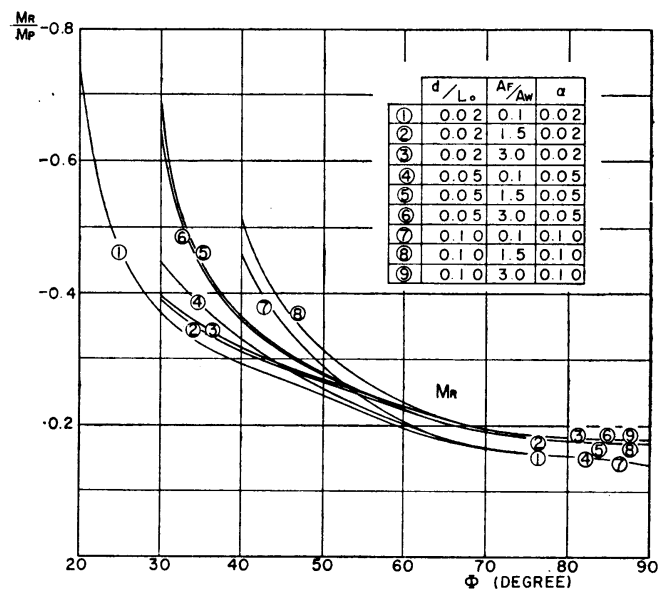

に増加しているが残留軸方向力は $\phi=90^{\circ}$ からの減少と ともに増加している。

c) 塑性ヒンジ位置 表一7 および 表一8 は単一集 中荷重, 組み合わせ荷重に対する変形硬化荷重による塑 性ヒンジ $a$ および $b$ の位置および荷重位置を表示した ものである。用いたパラメーターの範囲においては, 塑 性ヒンジ $a$ の位置と集中荷重の作用位置とは一致した。
Fig. 26 Residual Thrust at Hinge " $b$ ".

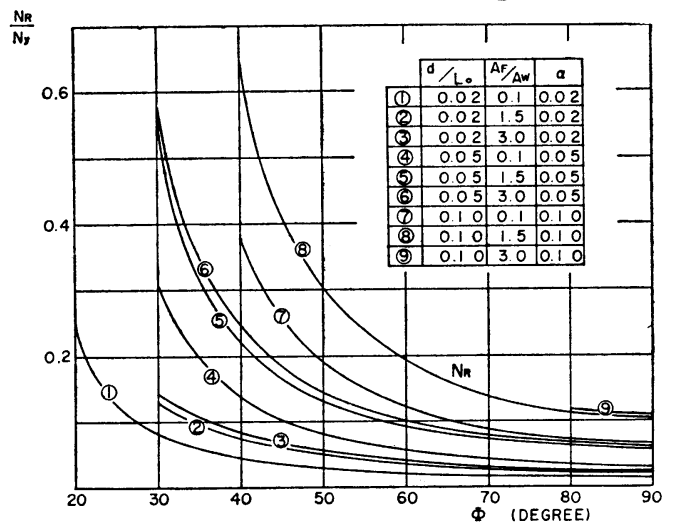

\section{（3）交番塑性荷重}

表一9 は交番塑性荷重の数值計算結果を示したもので ある。表一10 は交番塑性荷重により断面が破断する位 置 (上段) およびその荷重位置（下段）を示した。

\section{（4）三荷重の比較}

変形硬化荷重はいかなる場合も崩壊荷重より小さいが ここで計算した範囲では崩壊荷重の $96 \%$ を下ることは ない。崩壊荷重に対する変形硬化荷重の比は $\phi=30^{\circ} \sim 50^{\circ}$ で最も小さく, 単一集中荷重のみによる場合は $\phi=90^{\circ}$ で最も大きくなる。図一27 および図一28 は単一集中荷 重と組み合わせ荷重に対する崩壊荷重と変形硬化荷重を 図示したものである。また，同図には交番塑性荷重を一 点鎖線で示してある。これによれば，交番塑性荷重は変

Fig. 27

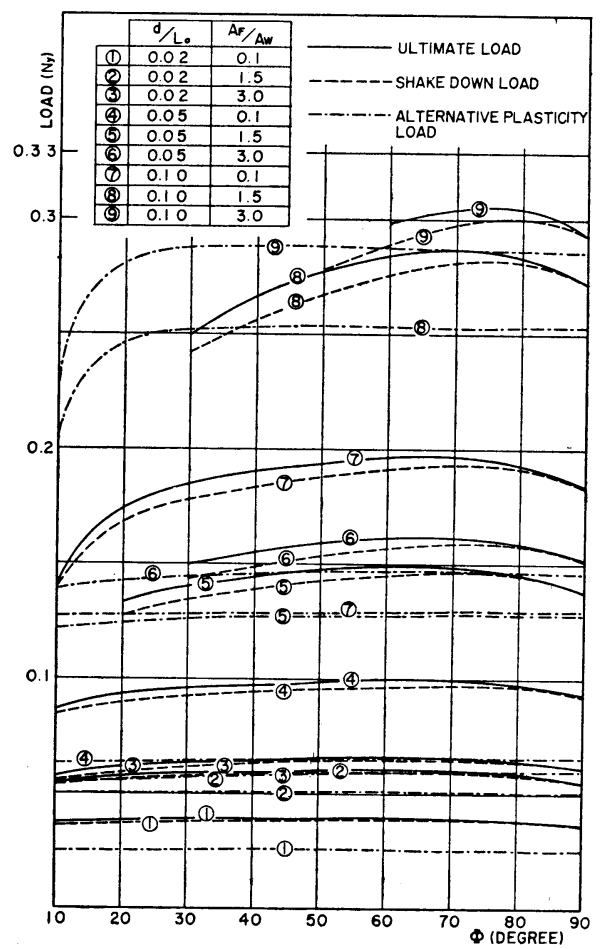


Table 7 Loading Points and Location of Plastic Hinge Formation under Shake-down Load (Concentrated Loading)

(DEGREE)

\begin{tabular}{|c|c|c|c|c|c|c|c|c|c|c|c|}
\hline \multirow{2}{*}{$d / L_{0}$} & \multirow{2}{*}{$A_{F} / A_{W}$} & & \multicolumn{9}{|c|}{$\phi$} \\
\hline & & & $10^{\circ}$ & $20^{\circ}$ & $30^{\circ}$ & $40^{\circ}$ & $50^{\circ}$ & $60^{\circ}$ & $70^{\circ}$ & $80^{\circ}$. & $90^{\circ}$ \\
\hline \multirow{9}{*}{0.02} & \multirow{3}{*}{0.1} & $\psi_{a}$ & 6.24 & 12.61 & 18.75 & 24.28 & 28.61 & 31.64 & 31.90 & 27.13 & 4.07 \\
\hline & & $\psi_{b}$ & 3.92 & 7.97 & 12.21 & 16.59 & 21.39 & 26.82 & 32.48 & 38.88 & 45.54 \\
\hline & & $\theta_{b}$ & 4.08 & 8.03 & 11.64 & 15.00 & 17.45 & 19.72 & 20.92 & 20.71 & 18.75 \\
\hline & \multirow{4}{*}{1.5} & $\psi_{a}$ & 6.24 & 12.61 & 18.75 & 24.08 & 28.61 & 31.64 & 31.90 & 27.13 & 5.32 \\
\hline & & $\psi_{b}$ & 4.24 & 8.10 & 12.36 & 16.79 & 21.39 & 26.82 & 32.48 & 38.88 & 45.54 \\
\hline & & $\theta_{b}$ & 3.76 & 7.65 & 11.40 & 14.69 & 17.65 & 19.72 & 20.92 & 20.46 & 18.75 \\
\hline & & $\psi_{a}$ & 6.16 & 12.61 & 18.60 & 24.08 & 28.61 & 31.64 & 31.90 & 27.29 & 6.20 \\
\hline & \multirow[t]{2}{*}{3.0} & $\psi_{b}$ & 4.16 & 8.10 & 12.36 & 16.79 & 21.39 & 26.82 & 32.48 & 38.88 & 45.54 \\
\hline & & $\theta_{b}$ & 3.52 & 7.65 & 11.40 & 14.69 & 17.65 & 19.72 & 20.70 & 20.50 & 18.57 \\
\hline \multirow{9}{*}{0.05} & \multirow{4}{*}{0.1} & $\psi_{a}$ & 6.16 & 12.61 & 18.60 & 24.08 & 28.61 & 31.64 & 31.90 & 27.29 & 6.20 \\
\hline & & $\psi_{b}$ & 4.16 & 8.10 & 12.36 & 16.79 & 21.39 & 26.82 & 32.48 & 38.88 & 45.54 \\
\hline & & $\theta_{b}$ & 3.52 & 7.65 & 11.40 & 14.69 & 17.65 & 19.72 & 20.77 & 20.50 & 18.57 \\
\hline & & $\psi_{a}$ & 5.22 & 12.14 & 18.36 & 24.03 & 28.61 & 31.64 & 32.12 & 27.50 & 9.08 \\
\hline & \multirow[t]{3}{*}{1.5} & $\psi_{b}$ & 4.50 & 8.40 & 12.36 & 16.79 & 21.65 & 26.82 & 32.48 & 38.88 & 45.82 \\
\hline & & $\theta_{b}$ & 2.90 & 7.12 & 11.06 & 14.44 & 17.39 & 19.56 & 20.52 & 20.25 & 18.29 \\
\hline & & $\psi_{a}$ & - & - & 18.06 & 23.72 & 28.61 & 31.64 & 32.26 & 27.91 & 11.07 \\
\hline & \multirow[t]{2}{*}{3.0} & $\psi_{b}$ & - & - & 12.75 & 17.00 & 21.65 & 26.82 & 32.62 & 38.88 & 45.93 \\
\hline & & $\theta_{b}$ & - & - & 10.44 & 14.03 & 17.01 & 19.26 & 20.38 & 20.25 & 18.18 \\
\hline \multirow{9}{*}{0.10} & \multirow{4}{*}{0.1} & $\psi_{a}$ & 4.82 & 11.81 & 18.21 & 23.82 & 28.56 & 31.66 & 32.12 & 27.50 & 9.54 \\
\hline & & $\psi_{b}$ & 4.50 & 8.45 & 12.60 & 16.79 & 21.60 & 26.76 & 32.48 & 38.88 & 45.82 \\
\hline & & $\theta_{b}$ & 3.06 & 7.17 & 11.02 & 14.44 & 17.34 & 19.50 & 20.52 & 20.25 & 18.29 \\
\hline & & $\psi_{a}$ & - & 10.38 & 17.24 & 23.19 & 28.35 & 31.64 & 32.62 & 28.86 & 14.71 \\
\hline & \multirow[t]{2}{*}{1.5} & $\psi_{b}$ & - & 9.09 & 12.99 & 17.32 & 21.78 & 27.13 & 32.62 & 39.03 & 46.11 \\
\hline & & $\theta_{b}$ & - & 5.74 & 9.82 & 13.40 & 16.37 & 18.45 & 19.81 & 19.59 & 17.53 \\
\hline & & $\psi_{a}$ & - & - & - & 22.68 & 27.97 & 31.80 & 33.28 & 30.31 & 18.18 \\
\hline & \multirow[t]{2}{*}{3.0} & $\psi_{b}$ & - & - & - & 17.68 & 22.35 & 27.13 & 32.92 & 39.29 & 46.52 \\
\hline & & $\theta_{b}$ & - & - & - & 12.20 & 15.25 & 17.68 & 18.82 & 18.72 & 16.55 \\
\hline
\end{tabular}

Table 8 Loading Points and Locations of Hinge Formation.

(DEGREE)

\begin{tabular}{|c|c|c|c|c|c|c|c|c|c|c|c|}
\hline \multirow{2}{*}{$d / L_{0}$} & \multirow{2}{*}{$\alpha$} & \multirow{2}{*}{$A_{F} / A_{W}$} & & \multicolumn{8}{|c|}{$\phi$} \\
\hline & & & & $20^{\circ}$ & $30^{\circ}$ & $40^{\circ}$ & $50^{\circ}$ & $60^{\circ}$ & $70^{\circ}$ & $80^{\circ}$ & $90^{\circ}$ \\
\hline \multirow{9}{*}{0.02} & \multirow{9}{*}{0.02} & \multirow{4}{*}{0.1} & $\psi_{a}$ & 12.15 & 18.40 & 23.40 & 26.69 & 26.47 & 16.63 & 0.05 & 0.02 \\
\hline & & & $\psi_{b}$ & 7.93 & 12.89 & 18.23 & 24.40 & 31.52 & 39.37 & 47.66 & 56.62 \\
\hline & & & $\theta_{b}$ & 9.24 & 11.53 & 14.42 & 16.73 & 18.08 & 18.29 & 17.00 & 13.59 \\
\hline & & & $\psi_{a}$ & - & 18.32 & 23.62 & 27.48 & 28.60 & 23.95 & 0.52 & 0.06 \\
\hline & & \multirow[t]{2}{*}{1.5} & $\psi_{b}$ & - & 12.64 & 17.78 & 23.54 & 30.00 & 37.42 & 45.30 & 53.81 \\
\hline & & & $\theta_{b}$ & - & 11.68 & 14.52 & 16.98 & 18.63 & 18.94 & 17.91 & 14.79 \\
\hline & & \multirow{3}{*}{3.0} & $\psi_{a}$ & - & 18.32 & 23.62 & 27.48 & 28.95 & 25.00 & 1.52 & 0.13 \\
\hline & & & $\psi_{b}$ & - & 12.73 & 17.67 & 23.40 & 29.83 & 37.04 & 44.90 & 53.13 \\
\hline & & & $\theta_{b}$ & - & 11.59 & 14.52 & 16.98 & 18.63 & 19.08 & 18.08 & 15.09 \\
\hline \multirow{9}{*}{0.05} & \multirow{9}{*}{0.05} & \multirow{4}{*}{0.1} & $\psi_{a}$ & - & 17.79 & 23.15 & 26.60 & 26.50 & 16.84 & 0.35 & 0.13 \\
\hline & & & $\psi_{b}$ & - & 12.81 & 18.37 & 24.56 & 31.57 & 39.49 & 47.70 & 56.81 \\
\hline & & & $\theta_{b}$ & - & 12.20 & 14.40 & 16.55 & 17.93 & 18.06 & 16.91 & 13.25 \\
\hline & & & $\psi_{a}$ & - & 17.10 & 23.15 & 27.19 & 28.60 & 24.18 & 2.91 & 0.39 \\
\hline & & \multirow[t]{3}{*}{1.5} & $\psi_{b}$ & - & 12.55 & 18.02 & 23.69 & 30.35 & 37.65 & 45.60 & 54.18 \\
\hline & & & $\theta_{b}$ & - & 12.73 & 14.29 & 16.55 & 18.10 & 18.47 & 17.38 & 14.30 \\
\hline & & & $\psi_{a}$ & - & 16.66 & 22.92 & 27.33 & 28.95 & 25.41 & 6.88 & 0.66 \\
\hline & & \multirow[t]{2}{*}{3.0} & $\psi_{b}$ & - & 12.81 & 18.13 & 23.83 & 30.17 & 37.45 & 45.36 & 53.66 \\
\hline & & & $\theta b$ & - & 12.29 & 13.81 & 16.10 & 17.76 & 18.27 & 17.14 & 14.30 \\
\hline \multirow{9}{*}{0.10} & \multirow{9}{*}{0.10} & \multirow{4}{*}{0.1} & $\psi_{a}$ & - & 15.78 & 22.45 & 26.17 & 26.33 & 17.04 & 1.05 & 0.39 \\
\hline & & & $\psi_{b}$ & - & 12.11 & 18.60 & 25.00 & 32.10 & 39.90 & 48.16 & 57.07 \\
\hline & & & $\theta_{b}$ & - & 15.00 & 14.40 & 16.11 & 17.41 & 17.45 & 16.21 & 12.73 \\
\hline & & & $\psi_{a}$ & - & - & 21.52 & 26.60 & 28.60 & 25.20 & 8.51 & 1.44 \\
\hline & & 1.5 & $\psi_{b}$ & - & - & 18.72 & 24.71 & 31.22 & 38.67 & 46.76 & 55.23 \\
\hline & & & $\theta_{b}$ & - & - & 13.70 & 15.09 & 16.53 & 16.84 & 15.74 & 12.46 \\
\hline & & & $\psi_{a}$ & - & - & - & - & - & - & 14.11 & 2.76 \\
\hline & & 3.0 & $\psi_{b}$. & - & - & - & - & - & - & 47.00 & $\mathbf{5 5 . 5 0}$ \\
\hline & & & $\theta_{b}$ & - & - & - & - & - & - & 14.34 & 11.15 \\
\hline
\end{tabular}


Table 9 Alternative Plasticity Load.

$\left(\times N_{y}\right)$

\begin{tabular}{|c|c|c|c|c|c|c|c|c|c|c|}
\hline \multirow{2}{*}{$d / L_{0}$} & \multirow{2}{*}{$A_{F} / A_{W}$} & \multicolumn{9}{|c|}{$\phi$} \\
\hline & & $10^{\circ}$ & $20^{\circ}$ & $30^{\circ}$ & $40^{\circ}$ & $50^{\circ}$ & $60^{\circ}$ & $70^{\circ}$ & $80^{\circ}$ & $90^{\circ}$ \\
\hline \multirow{3}{*}{0.02} & 0.1 & 0.0256 & 0.0258 & 0.0259 & 0.0259 & 0.0260 & 0.0260 & 0.0261 & 0.0262 & 0.0264 \\
\hline & 1.5 & 0.0499 & 0.0505 & 0.0508 & 0.0510 & 0.0511 & 0.0511 & 0.0512 & 0.0514 & 0.0517 \\
\hline & 3.0 & 0.0570 & 0.0578 & 0.0582 & 0.0584 & 0.0585 & 0.0585 & 0.0586 & 0.0588 & 0.0592 \\
\hline \multirow{3}{*}{0.05} & 0.1 & 0.0636 & 0.0642 & 0.0645 & 0.0648 & 0.0648 & 0.0649 & 0.0650 & 0.0652 & 0.0656 \\
\hline & 1.5 & 0.1227 & 0.1250 & 0.1264 & 0.1275 & 0.1274 & 0.1271 & 0.1272 & 0.1275 & 0.1282 \\
\hline & 3.0 & 0.1397 & 0.1426 & 0.1446 & 0.1459 & 0.1457 & 0.1454 & 0.1454 & 0.1457 & 0.1464 \\
\hline \multirow{3}{*}{0.10} & 0.1 & 0.1280 & 0.1278 & 0.1288 & 0.1297 & 0.1295 & 0.1292 & 0.1293 & 0.1296 & 0.1302 \\
\hline & 1.5 & 0.2020 & 0.2480 & 0.2517 & 0.2551 & 0.2535 & 0.2521 & 0.2515 & 0.2515 & 0.2524 \\
\hline & 3.0 & 0.2173 & 0.2826 & 0.2875 & 0.2919 & 0.2896 & 0.2879 & 0.2869 & 0.2868 & 0.2876 \\
\hline
\end{tabular}

Table 10 Alternative Plasticity Load (Locations of Load)

(DEGREE)

\begin{tabular}{|c|c|c|c|c|c|c|c|c|c|c|c|}
\hline \multirow{2}{*}{$d / L_{0}$} & \multirow{2}{*}{$A_{F} / A_{W}$} & \multirow{2}{*}{$\psi$} & \multicolumn{9}{|c|}{$\phi$} \\
\hline & & & $10^{\circ}$ & $20^{\circ}$ & $30^{\circ}$ & $40^{\circ}$ & $50^{\circ}$ & $60^{\circ}$ & $70^{\circ}$ & $80^{\circ}$ & $90^{\circ}$ \\
\hline \multirow{3}{*}{0.02} & 0.1 & $\begin{array}{l}a \\
b\end{array}$ & $\begin{array}{l}5.66 \\
3.34\end{array}$ & $\begin{array}{r}11.08 \\
6.82\end{array}$ & $\begin{array}{l}16.34 \\
10.15\end{array}$ & $\begin{array}{l}21.19 \\
13.30\end{array}$ & $\begin{array}{l}25.48 \\
16.62\end{array}$ & $\begin{array}{l}29.29 \\
19.12\end{array}$ & $\begin{array}{l}32.17 \\
21.25\end{array}$ & $\begin{array}{l}33.88 \\
23.10\end{array}$ & $\begin{array}{l}33.86 \\
24.95\end{array}$ \\
\hline & 1.5 & $\begin{array}{l}a \\
b\end{array}$ & $\begin{array}{l}5.73 \\
3.15\end{array}$ & $\begin{array}{r}11.19 \\
6.63\end{array}$ & $\begin{array}{r}16.40 \\
9.94\end{array}$ & $\begin{array}{l}21.25 \\
13.08\end{array}$ & $\begin{array}{l}25.45 \\
16.85\end{array}$ & $\begin{array}{l}29.27 \\
19.30\end{array}$ & $\begin{array}{l}32.17 \\
21.45\end{array}$ & $\begin{array}{l}33.93 \\
23.26\end{array}$ & $\begin{array}{l}33.87 \\
25.14\end{array}$ \\
\hline & 3.0 & $\begin{array}{l}a \\
b\end{array}$ & $\begin{array}{l}5.79 \\
3.10\end{array}$ & $\begin{array}{r}11.21 \\
6.59\end{array}$ & $\begin{array}{r}16.40 \\
9.88\end{array}$ & $\begin{array}{l}21.30 \\
13.02\end{array}$ & $\begin{array}{l}25.42 \\
16.94\end{array}$ & $\begin{array}{l}29.27 \\
19.39\end{array}$ & $\begin{array}{l}32.17 \\
21.53\end{array}$ & $\begin{array}{l}33.93 \\
23.36\end{array}$ & $\begin{array}{l}33.91 \\
25.17\end{array}$ \\
\hline \multirow{3}{*}{0.05} & 0.1 & $\begin{array}{l}a \\
b\end{array}$ & $\begin{array}{l}5.73 \\
3.15\end{array}$ & $\begin{array}{r}11.21 \\
6.59\end{array}$ & $\begin{array}{r}16.40 \\
9.91\end{array}$ & $\begin{array}{l}21.30 \\
12.99\end{array}$ & $\begin{array}{l}25.39 \\
17.01\end{array}$ & $\begin{array}{l}29.23 \\
19.49\end{array}$ & $\begin{array}{l}32.19 \\
21.59\end{array}$ & $\begin{array}{l}33.92 \\
23.41\end{array}$ & $\begin{array}{l}33.91 \\
25.25\end{array}$ \\
\hline & 1.5 & $\begin{array}{l}a \\
b\end{array}$ & $\begin{array}{l}5.91 \\
2.94\end{array}$ & $\begin{array}{r}11.42 \\
6.18\end{array}$ & $\begin{array}{r}16.61 \\
9.40\end{array}$ & $\begin{array}{l}21.46 \\
12.49\end{array}$ & $\begin{array}{l}25.27 \\
17.62\end{array}$ & $\begin{array}{l}29.17 \\
20.07\end{array}$ & $\begin{array}{l}32.16 \\
22.14\end{array}$ & $\begin{array}{l}33.94 \\
23.93\end{array}$ & $\begin{array}{l}34.04 \\
25.68\end{array}$ \\
\hline & 3.0 & $\begin{array}{l}a \\
b\end{array}$ & $\begin{array}{l}5.99 \\
2.81\end{array}$ & $\begin{array}{r}11.50 \\
6.06\end{array}$ & $\begin{array}{r}16.67 \\
9.29\end{array}$ & $\begin{array}{l}21.49 \\
12.37\end{array}$ & $\begin{array}{l}25.21 \\
17.83\end{array}$ & $\begin{array}{l}29.12 \\
20.25\end{array}$ & $\begin{array}{l}32.15 \\
22.31\end{array}$ & $\begin{array}{l}34.00 \\
24.08\end{array}$ & $\begin{array}{l}34.07 \\
25.82\end{array}$ \\
\hline \multirow{3}{*}{0.10} & 0.1 & $\begin{array}{l}a \\
b\end{array}$ & $\begin{array}{l}5.80 \\
3.21\end{array}$ & $\begin{array}{r}11.36 \\
6.32\end{array}$ & $\begin{array}{r}16.56 \\
9.54\end{array}$ & $\begin{array}{l}21.43 \\
12.58\end{array}$ & $\begin{array}{l}25.21 \\
17.74\end{array}$ & $\begin{array}{l}29.10 \\
20.19\end{array}$ & $\begin{array}{l}32.15 \\
22.21\end{array}$ & $\begin{array}{l}33.94 \\
23.99\end{array}$ & $\begin{array}{l}34.00 \\
25.75\end{array}$ \\
\hline & 1.5 & $\begin{array}{l}a \\
b\end{array}$ & $\begin{array}{l}1.65 \\
9.90\end{array}$ & $\begin{array}{r}11.70 \\
5.75\end{array}$ & $\begin{array}{r}16.89 \\
8.81\end{array}$ & $\begin{array}{l}21.66 \\
11.78\end{array}$ & $\begin{array}{l}24.85 \\
19.25\end{array}$ & $\begin{array}{l}28.92 \\
21.50\end{array}$ & $\begin{array}{l}32.09 \\
23.47\end{array}$ & $\begin{array}{l}34.01 \\
25.12\end{array}$ & $\begin{array}{l}34.24 \\
26.68\end{array}$ \\
\hline & 3.0 & $\begin{array}{l}a \\
b\end{array}$ & $\begin{array}{l}8.51 \\
9.90\end{array}$ & $\begin{array}{r}11.77 \\
5.60\end{array}$ & $\begin{array}{r}16.98 \\
8.60\end{array}$ & $\begin{array}{l}21.77 \\
11.52\end{array}$ & $\begin{array}{l}24.78 \\
19.70\end{array}$ & $\begin{array}{l}28.87 \\
21.94\end{array}$ & $\begin{array}{l}32.06 \\
23.86\end{array}$ & $\begin{array}{l}34.05 \\
25.41\end{array}$ & $\begin{array}{l}34.31 \\
26.96\end{array}$ \\
\hline
\end{tabular}

Fig. 28

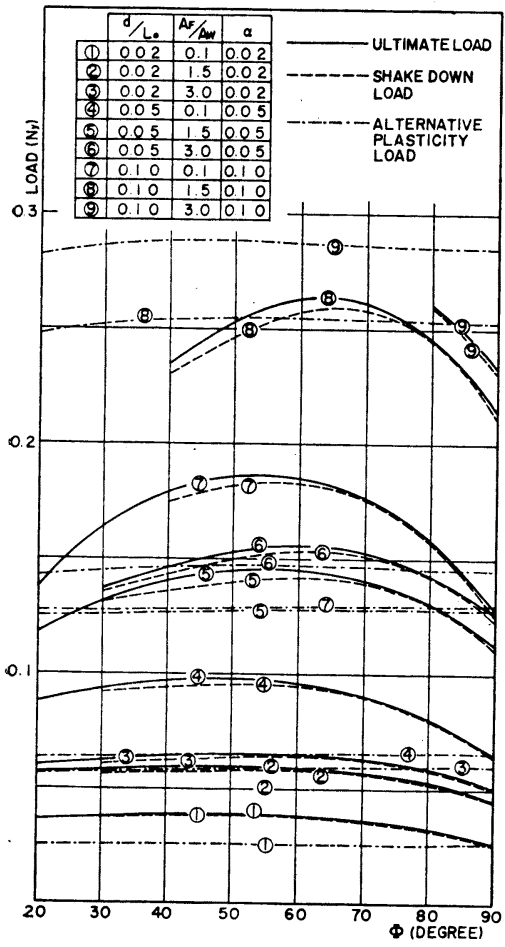

形硬化荷重よりも常に下まわっており, 等分布荷重係数 ๙の値により両荷重差はいちじるしく影響をうける。

\section{7. 結論}

本研究は軸方向力と曲げモーメントが作用する構造物 の変動くり返し荷重による崩壊機構を明らかにする研究 の一部として 2 ヒンジ円弧アーチにくり返し通過荷重が 作用するときのアーチの崩壊機構について理論的考察を 行なった。集中荷重, 等分布荷重および両荷重の組み合 わせ荷重によるアーチの塑性変形による崩壊荷重, 変形 硬化荷重, 交番塑性荷重および塑性ヒンジ形成の位置を アーチの中心角, スパン, 断面寸法をパラメーターとし て求め, 数值計算結果を数表と図表にまとめた。用いた アーチ リブ断面は矩形, 箱形または 2 軸対称工形断面 である。

得られた主な結論はつぎのようである。

（1）与えられたアーチ諸元に対する最小崩壊荷重, 同作用位置, 塑性ヒンジ形成位置は 表一1 から 表-6 の数表により求めることができる。

（2）崩壊メカニズムをもとに求められる最小崩壊荷 重による塑性ヒンジ形成位置 $\left(\psi_{a}, \psi_{b}\right)$ と変形硬化荷重 による塑性ヒンジ形成位置 $\left(\psi_{a}, \psi_{b}\right)$ は集中荷重のみで 
は 表一5 と表一7 に, 組み合わせ荷重では 表一6 およ び 表一8 にそれぞれ示してある。崩壊荷重による塑性 ヒンジ位置 $\left(a, b\right.$ 点) は $\phi<90^{\circ}$ では, 変形硬化荷重 による塑性ヒンジ位置より $a, b$ 点とも内側に生ずるこ とになる。

（3）崩壊荷重と変形硬化荷重との比較は表一1 およ び表一3に与えられているが, 両者の差はほとんどなく 最大約 $5 \%$ 前後の開きがあるのみで, 実用上は両者の差 は無視しうる。

（4）くり返し移動荷重により交番曲げモーメントが 断面 $a$ （表一10）に生ずるが，この交番曲げモーメント により断面に発生する交番塑性のためアーチは交番塑性 崩壊する。この荷重は用いたアーチ諸元では変形硬化荷 重よりも下まわる結果となり, その差は 図一27 および 図一28 に示してある。等分布死荷重を考える 組み合わ せ荷重では両者の比は接近してくるが，アーチの塑性解 析には, 崩壊荷重と, 交番塑性荷重の両者の検討が必要 となる。

本研究における数值計算はすべて金沢大学電子計算機 NEAC-2230 を使用した。

\section{8. 記号}

$$
\begin{aligned}
A=A_{F}+A_{W} & =\text { アーチ リブ全断面積 } \\
A_{F} & =\text { フランジ全断面積 } \\
A_{W} & =\text { ウェブ断面積 } \\
d & =\text { アチ リブの高さ } \\
d_{w} & =\text { アーチ リブのウェブ高さ } \\
H_{R} & =\text { 残留水平反力 } \\
I & =\text {-チ リブの断面 } 2 \text { 次モーメント } \\
i_{A}\left(i_{B}\right) & =A(B) \text { 支点の反力の水平となす角 } \\
k\left(k^{\prime}\right) & =\text { 降伏条件式の断面に関する倸数 } \\
L_{0} & =\text { アーチの半スパン長 } \\
M & =\text { 作用曲げモーメント }
\end{aligned}
$$

$$
\begin{aligned}
& M_{a x}\left(M_{b x}\right)=X \text { 点に集中荷重が作用した場合の } a(b) \\
& \text { 点の曲げモーメント } \\
& M_{R}=\text { 残留曲げモーメント } \\
& M_{R a}\left(M_{R b}\right)=a(b) \text { 点における残留曲げモーメント } \\
& M_{p}=\text { 全塑性モーメント } \\
& N_{a x}\left(N_{b x}\right)=X \text { 点に集中荷重が作用した場合の } a(b) \\
& \text { 点の軸方向力 } \\
& N_{R}=\text { 残留軸方向力 } \\
& N_{R a}\left(N_{R b}\right)=a(b) \text { 点仁作用する残留軸方向力 } \\
& N_{y}=A \sigma_{y}=\text { 軸方向力のみによる全断面降伏力 } \\
& P=\text { 集中荷重 } \\
& R_{A}\left(R_{B}\right)=A(B) \text { 支点反力 } \\
& w=\text { 等分布荷重 } \\
& Z=\text { 塑性断面係数 } \\
& \alpha=\text { 等分布死荷重係数 } \\
& \theta=\text { 集中荷重の作用位置 } \\
& \theta_{a}\left(\theta_{b}\right)=a(b) \text { 点に塑性ヒンジが形成される集中 } \\
& \text { 荷重の作用位置 } \\
& \text { ある断面に最大（最小）応力を生ぜしめ } \\
& \text { る集中荷重の作用位置 } \\
& \sigma_{y}=\text { 降伏点応力度 } \\
& \psi_{a}\left(\psi_{b}\right)=\text { 塑性ヒンジ } a(b) \text { の位置 } \\
& \text { 参支献 }
\end{aligned}
$$

1) Onat, E.T. and Prager, W. : "Limit Analysis of Arches", J. of Mech. and Phys. of Solids, 1, p. 73, 1953

2）“建築構造物のリミットフナリシス”, 日本建築学会, 第 4 章アーチ, 技報堂, 1963

3) Franciosi; V., Augusti, G., and Sparacio, R. : "Collapse of Arches Under Repeated Loading", ASCE Proc., ST 1, February 1964

4) "Commentary on Plastic Design in Steel", ASCEWRC, Manual of Engineering Practice No. 41, 1961

(1966. 2. $8 \cdot$ 受付) 